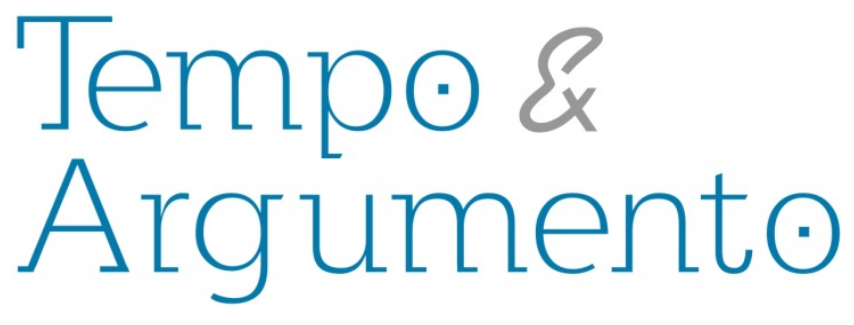

\title{
Paisagem de cacos e dores revoltadas: as marginalias da ditadura em livros de uma biblioteca universitária
}

\begin{abstract}
Resumo
Esse artigo resulta da formação de uma coleção de marginalias encontradas em livros relacionados à ditadura, presentes na Biblioteca Central da Universidade de Brasília. Essas marginalias (anotações, intervenções gráficas, interferências no texto e nos elementos para-textuais), mostraram-se particulares por seu sentido político, tanto no que se refere ao conteúdo quanto à circulação de opiniões e críticas que elas configuraram. Elas são analisadas, aqui, diante do pano de fundo das questões relativas à memória da ditadura militar, às políticas da ditadura sobre as mídias, em particular a circulação dos impressos e, em especial, a biblioteca como lugar de memória.
\end{abstract}

Palavras-chave: Biblioteca Universitária - Brasília, DF. Brasil - História - 1964-1985. Ditadura e Ditadores.

Escrita.

\author{
Daniel Barbosa Andrade de Faria \\ Doutor em História pela Universidade \\ Estadual de Campinas (Unicamp). Professor \\ do departamento de história da Universidade \\ de Brasília (UnB). \\ Brasília, DF - Brasil \\ krmazov@hotmail.com
}

\section{Para citar este artigo:}

FARIA, Daniel. Paisagem de cacos e dores revoltadas: as marginalias da ditadura em livros de uma biblioteca universitária. Revista Tempo e Argumento, Florianópolis, v. 9, n. 21, p. 243 289. maio/ago. 2017. 


\title{
Landscape of shards and revolted pains: the dictatorship's marginalia in books from a university library
}

\begin{abstract}
This article exposes the formation of a collection of marginalia found in books related to the military dictatorship, found in the Central Library of the University of Brasilia. These marginalia (notes, graphical interventions, interferences in the textual and para-textual elements) have proved to be specific in their political sense, in terms of the content and the communication network that they have created. Here they are analyzed in the context of themes related to the memory of the military dictatorship, the policies of the dictatorship on the media, particularly the circulation of printed material and especially the library as a place of memory.
\end{abstract}

Keywords: University Library - Brasília, Df. Brazil - History -1964-1985. Dictatorship And Dictators. Writing.

O título desse artigo é a junção de dois versos do poema "Imprensa", de Carlos Drummond de Andrade (ANDRADE, 1983, p. 640-642). A paisagem de cacos e dores revoltadas, no poema, resulta da intervenção de um jornal de imprensa oposicionista, satírica, numa pequena cidade mineira. A manhã de domingo, que seria de porcelana rosa, é estilhaçada pela intervenção do pasquim no cotidiano dos moradores. Os cacos, estilhaços da própria manhã rósea, e as dores revoltadas podem tanto se referir à virulência da imprensa alternativa e a disseminação da discórdia, quanto aos dissabores que a intervenção provoca no público leitor. O título do pasquim poetizado é O Raio e ele de fato irrompe como uma espécie de relâmpago enviado por um deus vingativo, expondo as divisões, intrigas e injustiças que estão ocultas na cidade, aparentemente pacificada - e mesmo parada no tempo. Cidade, por sinal, também pequena, bem distante da imagem que poderíamos ter de uma metrópole, onde se decidem os destinos da humanidade. 
O poema de Drummond foi publicado na sequência dos livros intitulados Boitempo, que lidam explicitamente com a questão da memória. O boitempo é o tempo que se rumina, ou o tempo que persiste em avançar lentamente, obstinado - e que retorna sempre ao mesmo ponto de partida. Inscrita nessa ideia de memória, a imagem dos cacos aparece em outros poemas dessa série. Como no caso de "O colecionador de cacos", comentado por Finazzi-Agrò (2013, p. 86-87). Para o crítico italiano, o colecionador de cacos de Drummond consubstanciaria uma das imagens mais fortes para o trabalho da memória, numa terra fundada na espoliação de suas próprias origens (míticas), numa história em que se colecionam passados como uma constante ruminação de traumas. O colecionador de cacos passa seu tempo a desenterrar restos de louça, esquecidos na horta de seu quintal. Esses restos, preservando uma imagem vaga de sua cor enquanto vivos, ferem os dedos; são, ao mesmo tempo, "vidro agressivo" e "ouro desprezado". Ainda seguindo a leitura de Ettore Finazzi-Agrò, o gesto desse colecionador (historiador, memorialista) é, simultaneamente, arqueológico e genealógico. Expressa o amor pelo início, pelos fundamentos enterrados e também busca os sinais indicativos de uma filiação. Não que o resultado disso seja alguma memória feliz, ou justa. Os tais fundamentos não passam de restos. A filiação, de um jogo incerto entre heranças diferentes e desencontradas.

Trazendo essas imagens e conceitos para o tema mais específico desse artigo: nele se trata exatamente da exposição de um gesto de colecionador. Aqui, a coleção é de comentários, rabiscos, intervenções gráficas, nos livros da biblioteca de uma universidade que passou boa parte de sua história em tensão constante com um governo ditatorial. Esses rabiscos foram se destacando, lentamente, de tantos outros que são tão comuns em livros de bibliotecas públicas. Comumente, trata-se de anotações para fins de estudo, sublinhados para apoio mnemônico - visando, provavelmente, avalições ou seminários. Os rabiscos, marginalias, que perfazem a coleção aqui apresentada em alguns de seus exemplos, porém, dirigiam-se a algum outro, ou outros, que não seu autor. Não eram lembretes ou notas de estudo e sim inscrições polêmicas, advertências contra o conteúdo de certos livros - muitas vezes sob a forma de explosões miúdas de revolta e indignação ou mesmo verdadeiras intervenções editoriais, mais ou menos sutis. Alguns livros se 
Que não se perca, porém, a lucidez diante da humildade e pequenez dessa coleção de cacos inscritos em livros. Não estamos diante de atos heroicos - na verdade, praticamente nada sabemos sobre quem fez as tais inscrições - e nem mesmo, exatamente, quando elas foram feitas. No que nos concerne, elas podem ter sido feitas por mero desabafo, um incômodo que não durou mais do que um dia. Podem ter sido feitas em momentos de grande perigo, em que a universidade estava sob vigilância cerrada e em que qualquer gesto poderia ser o pretexto de uma perseguição. Porque a universidade em questão, a UnB, teve seus dias de invasão militar, com direito a tiros e bombas de gás lacrimogêneo. Entre seus estudantes e professores, dezenas foram alvos de torturas sistemáticas - alguns estão, ainda hoje, na lista dos desaparecidos políticos da ditadura. Nos arquivos da polícia política da ditadura, temos, inclusive, documentos que relatam detenções de estudantes por motivos os mais irrisórios - como, por exemplo, ter cópias de textos de Karl Marx em suas moradias. Ou, ainda, fora desses momentos de repressão mais intensa, as marginalias podem ter sido feitas em situações em que o terror de Estado mostrava sua feição de fragilidade e decadência - quando, então, era possível recriar a imagem dos agentes do terror numa estética do risível, nas imagens paradoxais de tiranos enfraquecidos. De qualquer modo: naqueles anos, como as pessoas saberiam se estavam ou não em perigo, quando essa mesma definição ficava ao sabor dos arbítrios do momento? Por tudo o que se sabe sobre a "comunidade de informações", nada impedia que uma leitura orientada para o combate à "guerra revolucionária" visse nesses rabiscos pontas-de-lança do Comunismo Internacional (FICO, 2001).

Paradoxalmente, mesmo para um colecionador de cacos e não um agente treinado segundo o regime de signos despótico-paranoico (DELEUZE; GUATTARI, 2008, p. 61-107), esses rabiscos têm um considerável poder de sobrevivência. O seu poder de gerar memórias é, no mínimo, igual ao da sobrevivência da biblioteca que os acolhe. O intuito dos livros rabiscados, por sua vez, não era modesto, eles vislumbravam um grande futuro 
disciplinas como a de "Estudos dos Problemas Brasileiros", que tinham como meta moldar uma nova geração de jovens identificados com a grandeza potencial desse país e não os suspeitos, marginais e subversivos que estariam sendo reeducados. Ou então tratados sobre a guerra que se travava em nome da salvação da humanidade - ao menos, da civilização cristã ocidental. Obras de um interventor que atuou na Reitoria, um oficial da Marinha de quem se suspeitava que tinha sido especialmente treinado para o exercício da hipervigilância e da supermemória, já que aparentemente sabia tudo sobre todos que conviviam no seu campus, da sua universidade.

É certo que todos esses anseios grandiosos hoje parecem perdidos no tempo, como se um raio tivesse irrompido sobre eles, revelando a pequenez inscrita em seus anseios de grandeza - quase como meros pretextos a serviço de um Estado policial. Mas o registro de seus anseios monumentais sobrevive, e junto com ele, os cacos. A biblioteca da UnB - e quantas outras não terão esses mesmos traços em suas coleções de livros acabou se tornando uma espécie de arquivo involuntário da ditadura. Mais rico, certamente, porque seus livros voltados para um futuro supostamente radioso (que é nosso presente) estão rabiscados. E talvez até mais vivo, porque os rabiscos guardam gestos, corpos, existências e momentos singulares - embora isso provavelmente não passe de ilusão midiática. De qualquer modo, em síntese: a biblioteca e seus livros se tornaram canais midiáticos por onde, apesar de seu propósito inicial, essas vozes passam - atravessam o tempo e nos atingem. Em artigo recente, um pesquisador no tema falou em "inscrição frágil” da memória da ditadura militar no presente (PEREIRA, 2015). Podese dizer que esses livros estão entre tantos outros objetos que materializam, quase literalmente, essas inscrições frágeis. Por despertarem um passado-presente ainda doloroso e não resolvido, podem provocar movimentos de denegação e esquecimento forçado. Porém, como observa o autor do artigo supracitado: o gesto de denegar acaba preservando, em si mesmo, o traço daquilo que denega. 


\section{Sobre revoltas simbólicas e os perigos da comunicação}

Curiosamente (pensando em nosso contexto ditatorial), 1968 foi um ano propício para reflexões sobre as relações entre escrita e política - daí que nossas fontes se confundam com nossos aportes teóricos ao tema. Na França, o pensador Maurice Blanchot, a partir de sua experiência no comitê de escritores-estudantes do maio de 68, teorizou sobre o que ele considerava ser uma nova força da escrita. Nos impressos que circulavam, nas pichações em muros, havia uma escrita marcada pela proliferação de textos sem assinatura, mas não por isso uniformes, homogêneos. Pelo contrário esta seria uma escritura heterogênea, plural. Para Blanchot, essa escritura emergiria contra os privilégios tradicionais da autoria, do livro fechado em si mesmo e pretenso portador da verdade. Nessa escrita específica, o anonimato não serviria como proteção ao autor do texto e sim como construção de uma fala coletiva, sem proprietário. Além disso, os textos seriam fragmentários, inacabados, assim preservando a pluralidade da política, a conjunção-disjunção das relações entre diferenças. Num viés que pode ser considerado uma espécie de utopia da escrita, em síntese, Blanchot dizia que nessa escrita de 1968 a linguagem não seria mais organizada por um conteúdo estruturado, e sim pelas relações que ela propiciava, pela assembleia dos falantes, o conjunto de vozes em "desacordes" que constituiriam interrogações incessantes (BLANCHOT, 2008, p. 149-151).

Não que se considere, aqui, que o maio de 1968 francês seja um modelo explicativo para tudo o que aconteceu no Brasil em torno dessa data, antes e depois. As diferenças são notáveis, a começar pela violência do Estado policial - e em seguida pela duração da ditadura, pela difícil resistência que durou décadas. Mas também não compartilhamos da visão derrisória sobre o chamado "pensamento de 68" - por vezes até satirizado pelo fato de que suas "súmulas" são coleções de pichações e grafites urbanos (por exemplo: LEWINO, 1968; TCHOU, 1968). Como observa De Certeau (1998, p. 10), ele mesmo um observador envolvido nos acontecimentos de maio de 1968, considerar que uma revolução (derrotada) tenha se dado no plano do simbólico exige duas cautelas, ao menos. A primeira é lembrar-se que tomar a palavra não é o mesmo que tomar o poder, a não ser que, ingenuamente, acredite-se no poder mágico da linguagem. A segunda é que dessa fragilidade se concluir que o simbólico é insignificante seria supor 
que toda sociedade é um mero mecanismo, que, em síntese, é possível uma sociedade sem seres humanos.

Não por acaso, no acervo da assessoria do Serviço Nacional de Informações da Universidade de Brasília (fundo ASI/UnB do Arquivo Nacional), um dos temas mais comuns é o das publicações estudantis, dos panfletos, dos livros, dos manifestos. A repressão política considerava fundamental essa questão do nível simbólico das resistências. Por outro lado, também para as pessoas que lutavam contra a ditadura, dentro ou fora de organizações, a questão da comunicação era central - a manutenção de gráficas, de esquemas de publicação e distribuição de textos e denúncias, as práticas da pichação, a manutenção de mimeógrafos. Na ausência de uma mídia estudantil favorável à ditadura, o próprio Estado, por vezes, encarregava-se de criar, artificialmente, os seus movimentos e canais. Apenas a título de exemplo, em 07 de julho de 1971, a divisão do SNI do Ministério da Educação (DSI/MEC), enviou ao Reitor da UnB um documento, com vistas à sua "máxima divulgação possível entre o corpo discente". Assinado por um suposto Movimento Revolucionário de Participação, o documento era um panfleto que comentava a questão da repressão política. A tese central era a de que, baseando-se nas leis da física da ação e reação, todo movimento deflagrava as forças que o viriam a combater. Ou seja, os dissidentes seriam os responsáveis pela escalada da repressão. A proposta desse suposto MRP era o de que o sujeito revoltado se voltasse para si mesmo, para a construção da sua paz interior e, partindo disso, encontrasse um modo "não fratricida" de resolver os problemas políticos e sociais do país. O pressuposto desse falso movimento, que por sinal pode ser expandido ao modo como os agentes da ditadura pensavam sobre a universidade, era o de que o meio estudantil era prisioneiro do estado de uma revolta latente, uma dor miúda própria à juventude, mas também alimentada pela cultura de massas, pelos desejos sexuais em ebulição e, como não podia deixar de ser, pela conspiração mundial do comunismo.

Para citar uma figura ditatorial de dentro da universidade pública brasileira, o então Reitor da UFRJ, Djacir Menezes, afirmava:

\footnotetext{
${ }^{1}$ Arquivo Nacional. Memórias Reveladas. Acervo dos órgãos de informação do regime militar, Fundo ASI/UnB, BR ANDF AA1 o CMD 023.
} 
Uma propaganda insidiosa compôs uma imagem falsa do movimento estudantil com retalhos de Castro, Padre Camilo, Guevara, Debray, Marcuse, cozinhados nos refugos marxistas, com sexualismo e drogas. $O$ resultado da triaga de tantos ingredientes, que vão do aliciamento ideológico aos festivais de entorpecentes, é o desencanto diante do velho mundo burguês e de seus códigos morais, do qual retiram, como seiva para o protesto, o que há de mais podre e degenerado. (MENEZES, 1971, p.11-12)

De acordo com as orientações da polícia política da ditadura, a luta armada era apenas a expressão mais evidente de um processo mais amplo, a guerra revolucionária. Esta era alimentada por todos os processos tidos como subversivos, intencionas ou não. A corrupção dos costumes, a crítica à família, a disseminação do ateísmo, o consumo de entorpecentes também teriam seu papel na guerra em curso. A guerra, portanto, não era apenas armada ou militar, mas também psicológica, midiática. Tanto que, de acordo com Djacir Menezes e tantos outros documentos da época, a cultura de massas, a comunicação social, eram parte do problema, uma vez que rebaixavam o nível cultural, defendiam o hedonismo e a irresponsabilidade (outro exemplo nesse sentido: Ávila, 1978). Tudo isso confluindo para um ambiente de subversão que tornava o jovem uma presa fácil para o recrutamento do Comunismo Internacional.

Os manuais que o Ministério da Educação e Cultura, por meio de sua Divisão de Segurança e Informações, enviava para as assessorias de espionagem das universidades, são também bem explícitos nesse sentido. Por exemplo, na apostila intitulada Contra-Subversão, produzida no início da década de 1970, lê-se que as ações subversivas tinham um teor "predominantemente psicológico", visando a conquista progressiva da população, tanto em seus aspectos "físicos" quanto "emocionais". "subversão", de acordo com o serviço de inteligência da ditadura militar, procurava “influenciar opiniões, sentimentos e crenças e, portanto, modificar atitudes”. Ainda segundo o mesmo documento, "o rádio, a televisão, a imprensa, a distribuição de panfletos, as reuniões e conferências, o boato, são os meios de que a subversão se servirá para conseguir o efeito psicológico".

Em outra apostila do mesmo documento, intitulada “Persuasão”, lê-se que:

\footnotetext{
${ }^{2}$ Arquivo Nacional. Memórias Reveladas. Acervo dos órgãos de informação do regime militar, Fundo ASI/UnB BR ANDF AA1 o LGS 007.
} 
Vivemos dias difíceis, A Guerra Revolucionária constitui uma terrível realidade: está presente no país, na nossa cidade e busca atingir os nossos lares, o nosso livre arbítrio, o Comunismo tenta atingir nossas mentes, procura dominá-las. Tentativas de mudar nossas tradições democráticas estão sendo feitas, sem o recurso obrigatório à força física. Nesta época de Ideias conflitantes, nações inteiras são submetidas à persuasão coletiva graças aos novos meios de comunicação, às novas técnicas e à pressão de massas conduzidas por demagogos.

A propaganda comunista tem tentado, nas escolas, nos teatros e cinemas; nas músicas ditas de "protesto"; através de panfletos; na televisão e, principalmente, na imprensa escrita (onde a infiltração nas redações é enorme) e no mundo dito dos "intelectuais", modificar as atitudes normais e gerais do homem brasileiro.

Haveria, inclusive, uma linguagem específica da chamada subversão, com suas marcas: a substituição de termos favoráveis por outros desfavoráveis ao governo, a conotação emocional das palavras, os jargões - como, por exemplo, a substituição do termo "conservador" pelo "quadrado", “norte-americano" por "imperialistas”. O uso de slogans e palavras-chave, que tornavam o público propenso a negligenciar seus efeitos e mesmo a aderir à subversão. A guerra midiática se basearia ainda na crença de que uma afirmação repetida acabava se tornando uma "verdade".

Os exemplos poderiam ser multiplicados. Quando pensamos na ditadura militar brasileira, os múltiplos cercos à escrita são mais ou menos facilmente identificáveis. Não somente pela questão da censura, no controle sobre as gráficas, os mimeógrafos, os panfletos, as pichações. Na universidade, e no caso específico aqui estudado, a Universidade de Brasília, deparamo-nos com inúmeros casos nesse sentido. As máquinas de escrita eram consideradas tão "perigosas" ou "subversivas" quanto as armas. A Federação dos Estudantes da Universidade de Brasília protegia, incansavelmente, seu maior bem: um mimeógrafo (COMISSÃO ANÍSIO TEIXEIRA DE MEMÓRIA E VERDADE, 2016, p. 142).

A FEUB perdeu sua sede em 1968, mas continuou existindo, clandestinamente até 1971 - a perda do mimeógrafo é lembrada, pelos estudantes de então, como o fim da entidade. Além disso, estudantes foram torturados e interrogados sistematicamente sobre gráficas, aparelhos de escrita (como se pode ver em inúmeras passagens analisadas por Joffily, 2013). Além é claro, em contrapartida a essas escritas perseguidas, da imposição de uma escrita sobrecarregada de verdade e soberania, quase uma 
Sobre os panfletos, encontramos num importante Inquérito Policial-Militar sobre a UnB, em 1968, a seguinte análise:

Panfletos analisados por peritos usam técnica para inflamar e mobilizar a massa estudantil e operária: Os srs Peritos, ao responderem um dos quesitos formulados, quando o encarregado deste Inquérito indaga 'se o teor dos boletins e panfletos e a maneira como vem sendo incendiada a mocidade, são de molde a envenenar a classe estudantil e a incitar os ânimos na condução das massas para seus fins contra-revolucionários para a tomada progressiva do Poder', e como que sentenciando, expressaram de maneira brilhante: 'SIM, pois esta forma de propaganda vem preparando não só a opinião estudantil e mesmo a classe operária, como a própria condução das massas na direção de seus objetivos, uma vez que sua incitação já se faz direta e com objetivos certos, como bem demonstra o seguinte trecho do documento no 29 e intitulado MANIFESTO DO DCESB, onde se lê: 'aos soldados, sargentos conclamamos a se rebelarem contra as ordens de seus superiores, a se opor e impedir os planos da burguesia, do governo, de reprimir as manifestações e de aderir ao exemplo dos sargentos de Brasília, dos fuzileiros navais do Rio de 1963, e dos marinheiros na Revolução Russa de 1917, e a passar para o lado da população; e que lutem pelas liberdades democráticas dentro dos quartéis, pela organização sindical em massa dos soldados. ${ }^{3}$

E não apenas o Comunismo Internacional, nesses documentos, parece totalmente imerso numa guerra midiática, como os próprios serviços de inteligência foram estruturados midiaticamente. Além do desenho institucional dos órgãos de espionagem (que envolvia o Serviço Nacional de Informações e suas assessorias específicas em cada autarquia, os serviços de inteligência das forças armadas, o Departamento de Polícia Federal, chegando, na ponta extrema do cotidiano da Universidade de Brasília ao Serviço de Proteção do Patrimônio, os vigias que registravam em relatórios extensos e livros de ocorrência todo tipo de atividade política), havia uma rede de tecnologias e canais de comunicação: aparelhos de escuta, fotografias panorâmicas - tiradas, ao que tudo indica, de dentro do próprio prédio da Reitoria - comunicações via rádio, telegramas, livros de ocorrência, manuscritos ou impressos, e mesmo singelos bilhetinhos e recados manuscritos (PARUCKER, 2015).

\footnotetext{
${ }^{3}$ Arquivo Nacional. Memórias Reveladas. Acervo dos órgãos de informação do regime militar, Fundo SNI, BR DF AN BSB AAJ IPM 0130.
} 
Os próprios agentes de informação, de acordo com as apostilas do documento supracitado, deveriam se tornar, eles mesmos, canais midiáticos de preservação das informações e da "memória". Sendo que ali, a memória é definida como capacidade de retenção de informações, favorecida pelos mecanismos psíquicos do interesse, da atenção e do treinamento. O agente devendo, então, preparar-se para gravar em sua mente tudo o que pudesse ser usado para a preservação da ordem. E, depois de gravar, rememorar sempre que necessário. O perfeito agente da informação sendo, portanto, uma mistura de gravador e arquivo.

Quando tais mecanismos não bastavam, os agentes da ditadura militar recorriam a intervenções mais diretas. O próprio interventor, reitor José Carlos de Almeida Azevedo, enviou em 05 de agosto 1977 uma carta ao Diretor Presidente da Folha de São Paulo, Octavio Frias de Oliveira, protestando contra o teor da cobertura sobre acontecimentos de então na UnB (que se via paralisada por uma grande greve estudantil, depois de perseguições e punições a estudantes que tentavam reinaugurar o Diretório Central de Estudantes, mas com a pauta mais ampla da redemocratização do país). Segundo o interventor - por sinal também dotado de superpoderes no que se referia à memória, sendo capaz de lembrar nomes e rostos de praticamente qualquer estudante da universidade - a crise política na universidade era fruto de ações de pessoas malévolas que pretendiam levar o país ao caos. Os jornais, dizia, estavam apresentando versões deturpadas desse fato. Mesmo, em suas palavras, a responsabilidade não sendo tanto da linha editorial do jornal, e sim do trabalho de repórteres

\begin{abstract}
recém egressos de péssimas escolas de comunicação, onde ouvem sandices de Marcuses, McLuhans, "aldeias globais" e outras indigências mentais congêneres, mas que não são capazes de analisar um fato social ou político, estabelecer conceitos e esclarecer o público de forma correta, tudo isso ao gosto da imprensa inidônea e - permita-me a afirmação - deslustrando as tradições desse jornal. ${ }^{4}$
\end{abstract}

Para concluir essa parte sobre a questão das mídias, especialmente as escritas, e a ditadura militar, lembremos que um dos autores citados pejorativamente nessa carta à Folha de São Paulo, fez discussões muito interessantes sobre as relações entre

\footnotetext{
${ }^{4}$ Arquivo Nacional. Memórias Reveladas. Acervo dos órgãos de informação do regime militar, Fundo ASI/UnB, BR DF NA BSB AA1 O MPL 022
} 
a aceleração das mudanças seria o próprio paradigma do planejamento industrial e militar. Mcluhan ilustra essa questão com uma passagem da antropóloga Margaret Mead que, ao levar livros para as Ilhas do Pacífico, teria notado que o que mais surpreendeu os nativos não eram os livros em si, e sim a existência de vários exemplares de um mesmo livro. Diante disso, ainda segundo o autor, a função do artista seria o daquele capaz de furtar-se aos "golpes" das novas tecnologias, neutralizando sua violência. Uma intervenção desentorpecedora sobre os mecanismos das mídias (e não se pode deixar de destacar, aqui, que o tradutor desse livro, Décio Pignatari, estava entre os professores que pediram demissão da UnB em 1965, em protesto contra perseguições políticas na universidade).

A imagem da propaganda comunista, durante a Guerra Fria, era, em grande medida, a ideia de onipresença da mídia somada à suspeita de uma conspiração internacional. Era convincente para seus homens de inteligência, porque a imagem do agente secreto escondido por trás da proliferação de escritos, imagens, ideias, palavras se baseia na própria evidência da proliferação do midiático. Em linhas gerais, inclusive, tirando a questão da conspiração comunista, nessa documentação da ditadura o que temos é uma descrição muito parecida com a de qualquer estudo sobre mídia, propaganda, publicidade ou psicologia social. A sensação de que os meios de comunicação estão escondendo algo de nós seria parte de uma fenomenologia midiática, em que a proliferação de meios que remetem a outros meios, leva à questão angustiante de se saber, afinal de contas, quem é o sujeito que está manipulando tudo atrás dos bastidores (GROYS, 2012).

\section{A biblioteca universitária como canal midiático de memória da ditadura}

O que temos nas marginalias da biblioteca da UnB é um acervo de práticas de escrita plural, anônima, conflitiva, contestadora, irônica. Num ambiente em que, vale lembrar, todo tipo de dissensão era proibido. A paisagem de cacos e dores revoltadas, 
comentada no poema de Drummond sobre a imprensa miúda, opositora, panfletária; isso no que se refere aos livros eminentemente políticos publicados durante a ditadura militar. Algo como um tremor muito sutil vindo de uma revolta latente contra a repressão e as propostas pedagógicas do regime se deixa perceber.

Essas marginalias manuscritas em livros ditatoriais poderiam ser consideradas excessivamente banais para serem dignas de atenção historiográfica. Porém, há um certo consenso entre historiadores de que não existe prática que seja, em si mesma, irrelevante do ponto de vista histórico. De Certeau (1998a) sugere que é exatamente em torno de práticas comuns, anônimas, em que o corriqueiro é levemente modificado por sutis desvios, que podemos flagrar a inventividade da cultura. Ou seja, não podemos pressupor a banalidade como sinônimo de futilidade do cotidiano. O banal não é o fútil. Por outro lado, talvez numa leitura mais moral, essas práticas de intervenções em livros podem ser consideradas como meras "depredações do patrimônio público". Mas, antes desse tipo de julgamento moral, é preciso pensarmos no que está em jogo nestas e em outras práticas da escrita, num sentido político, sobretudo levando-se em consideração o contexto ditatorial das obras anotadas.

Jacques Rancière, em passagem inspiradora, diz:

O conceito de escrita é político porque é o conceito de um ato sujeito a um desdobramento e a uma disjunção essenciais. Escrever é o ato que, aparentemente, não pode ser realizado sem significar, ao mesmo tempo, aquilo que realiza: uma relação da mão que traça linhas ou signos com o corpo que ela prolonga; desse corpo com a alma que o anima e com os outros corpos com os quais ele forma uma comunidade; dessa comunidade com a sua própria alma. Na atenção apaixonada que as sociedades escolarizadas dão ao aprendizado da escrita e à posição correta do corpo do jovem aluno, mais ainda que à perfeição do que ele escreve, transparece um valor fundamental: antes de ser o exercício de uma competência, o ato de escrever é uma maneira de ocupar o sensível e de dar sentido a essa ocupação. Não é porque a escrita é o instrumento do poder ou a via real do saber, em primeiro lugar, que ela é coisa política. Ela é coisa política porque seu gesto pertence à constituição estética da comunidade e se presta, acima de tudo, a alegorizar essa constituição. (RANCIÈRE, 1995, p. 7)

Esta passagem de Rancière sugere que prestemos atenção às múltiplas implicações políticas da escrita (não somente pelo conteúdo dos textos, mas pelas 
impressas mecanicamente potencializavam o caráter anônimo e indeterminado dos textos, o que foi de grande importância, sobretudo diante das práticas dos primeiros Estados policiais. Por outro lado, sob o aspecto da soberania, dominar uma língua codificada e unificar, por meio dela, um território, foi um dos grandes objetivos dos Estados nacionais modernos.

Uma biblioteca pública, nesse sentido, é uma grande instituição da memória, um arquivo. Não só pelo fato de pretender abrigar em si tudo o que seria relevante (ou permitido) numa determinada cultura, mas também por classificar, ordenar os delineamentos gerais que definem o saber e deixam nas entrelinhas o não-saber. 0 conteúdo de uma biblioteca são seus livros, o conteúdo de seus livros são textos, linguagem escrita impressa. Mas não é apenas isso que perfaz a figura de uma biblioteca como uma instituição midiática. Fundamental também é o seu sistema classificatório, que uniformiza os livros em séries repetidas e que fragmenta essas séries em campos distintos. Sabe-se, ainda, que uma biblioteca como a da UnB, na ditadura, fazia as suas seleções prévias. Livros eram escondidos, e talvez mesmo destruídos. Ou então marcados como potencialmente subversivos. Ao mesmo tempo, certos livros eram erigidos como portadores da verdadeira cultura, voltados para a educação de um público jovem que, na visão da ditadura, quando não era subversivo, estava entorpecido pelos meios de comunicação de massa.

Assim, quando estudantes da UnB deixavam suas marginalias em livros ditatoriais, não estavam apenas expressando discordância ou sentimento de revolta, mas também efetivamente inventando um circuito alternativo de comunicação. Veremos adiante como a aparição de suásticas desenhadas em capas de livros formava uma outra lógica de classificação (a de livros fascistas - classificação essa imprevista pelo sistema da biblioteca). Por outro lado, quando escreviam seus comentários e respondiam a comentários de outros, criando um debate dentro das páginas do livro, a própria dinâmica da leitura era subvertida: não mais a leitura silenciosa para apreender o 
De acordo com Groys (2012, p. 34-35), os signos se tornam signos por sua presença em canais midiáticos. O texto, a linguagem escrita, é, em si mesmo, uma tecnologia midiática. O livro, por sua vez, é um canal de disseminação dessa tecnologia. Por sua vez, o livro está integrado em canais mais complexos, como arquivos e bibliotecas. Os quais, por sua vez, estão incluídos em redes complexas: políticas, sociais e mesmo biológicas.

Uma biblioteca, para um usuário despreocupado, aparenta ser uma mera coleção de livros colocados em estantes classificadas. Mas já esse dado evidente da classificação aponta para a existência de toda uma maquinaria institucional dando suporte à coleção de livros. Essa maquinaria seleciona o que vai entrar ou não na coleção, em que posição. Ou seja: em que horizonte de sentido. A questão da seleção é ainda mais sensível durante uma ditadura, quando livros considerados "subversivos" ou suspeitos, podem ser simplesmente eliminados ou mesmo marcados - marca de subversão ou suspeita devidamente transmitida para eventuais usuários. A biblioteca, por bons motivos, é um espaço de silêncio. A ideia é de que a leitura é um exercício silencioso, de assimilação do conhecimento disponível naqueles livros. Evidentemente, os leitores não são obrigados a seguir esse script, mas há uma clara divisão de trabalho entre produtores de linguagem e receptores. Por outro lado, uma biblioteca universitária pública tem o sistema de empréstimo e devolução. Ou seja: os livros circulam entre os usuários. Com isso, acabam suportes de uma rede latente, na medida em que, paralelamente à classificação da coleção e a colocação dos livros em estantes pré-definidas, os usuários fazem os livros circularem de mãos em mãos. Mas enquanto os usuários cumprem o papel de leitores silenciosos, devolvendo os livros intactos, trata-se, realmente, no máximo, de uma rede latente. Porém, quando os usuários passam a rabiscar os livros, escrever suas notas, responder por escritos às notas de outros usuários, usando o papel dos livros como suporte de produção de novas informações, a rede se configura como um canal de comunicação, produção de sentido, circulação de ideias e opiniões, de modo horizontal, uma vez que não há hierarquia entre os usuários. 
Não por acaso, a biblioteca é um ponto sensível da vida universitária, que por sua vez é um ponto sensível da vida política. O que, ao menos no que se refere à história da UnB, pode inclusive ser ilustrado por uma cronologia dos acontecimentos. A 20 de abril de 1967, o embaixador norte-americano John Tuthill esteve na Biblioteca da Universidade de Brasília, numa cerimônia comemorativa de doação de livros. Com a Guerra do Vietnã, e diante do apoio dos Estados Unidos à ditadura no Brasil, estudantes resolveram protestar. Depois da cerimônia e do protesto dos estudantes, o prédio da Biblioteca foi fechado e ali mesmo estudantes foram espancados e, de lá, sendo que 76 deles foram detidos (COMISSÃO ANÍSIO TEIXEIRA DE MEMÓRIA E VERDADE, 2016, p. 103). Na memória de ex-estudantes da universidade, esse evento da biblioteca foi o marco que definiu uma linha de ruptura na trajetória do movimento estudantil. A partir dali, o embate com a ditadura seria mais direto, e por vezes violento. A "guerra de salgadinhos", os livros que foram tirados das prateleiras e usados como tentativas de defesa, sendo jogados em policiais armados, eram apenas a antevisão em pequena escala do que viria nos anos seguintes.

\section{A coleção de cacos}

A coleção de cacos aqui comentada tem, hoje, cerca de 70 exemplares. O seu colecionador já foi até visto por amigos na biblioteca enquanto fazia sua coleção, o que sempre vinha com alguma indagação sobre o método de pesquisa (mesmo se ele estava consultando, um a um, todos os livros da biblioteca, como se fosse personagem de um conto de Jorge Luís Borges). Um amigo chegou a dizer, sem querer: "você ainda está procurando aqueles rabiscos"? A princípio, a palavra rabisco soou derrisória. Mas, com o tempo, foi se tornando mais simpática. Marginalia parece apenas um termo pedante, dedicado às anotações feitas por clássicos, autores canônicos da literatura universal. Por outro lado, marginalia remete a toda uma questão cultural dos anos 1960 e 1970, "seja marginal, seja herói”, ou à música de Gilberto Gil e Torquato Neto, "Marginalia 2". Fiquemos, então, com a ideia da coleção de marginalias e rabiscos. 
O critério de pesquisa não foi aleatório, embora tenha sido exaustivo. Foram privilegiados, na medida do possível, todos os autores emblemáticos da ditadura (a começar por presidentes, ministros e o interventor-reitor da UnB). Além disso, houve uma pesquisa temática, em buscas de assuntos como "estudos de problemas brasileiros", “ditaduras", "revoluções" ou por casos que se tornaram memoráveis como Cuba e Vietnã. Livros de opositores a ditaduras, ou autores relacionados ao marxismo, às esquerdas também foram consultados. Mas nesses, não se verificou o mesmo padrão encontrado nas marginalias dos livros ditatoriais. Não se podendo afirmar que seja uma característica exclusiva desses livros, mas o certo é que, nesse quesito dos rabiscos, eles têm suas particularidades que os destacam no corpus da biblioteca.

Não há nomes de autores individuais dos rabiscos, portanto a suposição de que sejam estudantes se deve ao seu estilo de protesto, à linguagem e, o mais evidente, ao fato de que esses livros eram basicamente usados por estudantes. A datação das marginalias também é incerta. Temos as datas em que os livros deram entrada na biblioteca, e nada mais. Em alguns casos, há os recibos de empréstimo, os quais ao menos dão uma ideia sobre quando esses livros foram consultados. Pelo seu teor, são livros que hoje interessam mais a pesquisadores especializados no assunto. É pouco provável que hoje, até mais do que nos anos 1960 a 1980, algum leitor pegaria um desses livros por mera curiosidade, entretenimento ou prazer estético. Como no caso exemplar dos livros de "estudos de problemas brasileiros", está registrado que seus últimos empréstimos datam da década de 1980. Depois, em alguns casos, há empréstimos esparsos - o que se pode atribuir à curiosidade insaciável dos pesquisadores, que vão despertar esse tipo de material do mundo dos mortos.

Mas, para não ficarmos num nível de análise muito genérica, passemos logo para alguns exemplos:

\subsection{Anotações em elementos paratextuais}

Uma nota inicial é que as marginalias incidem, quase sempre, sobre os elementos paratextuais (GENETTE, 2009): títulos, nome do autor, índices. Elementos editoriais que 

são, portanto, centrais para a instituição do livro como canal midiático, para além de sua eventual classificação de acordo com os parâmetros da biblioteca ou coleção em que ele será incluído. Por exemplo, o nome do autor, que só recentemente passou a constar das capas dos livros, não é uma mera assinatura: a função do autor confere autoridade ao texto (além de indicar elementos que podem induzir a determinadas interpretações sobre essa autoridade, como nacionalidade, gênero, entre outros). Os títulos são verdadeiras portas de entrada, que abrem a perspectiva do leitor para um determinado sentido do texto que ele tem em mãos. Não só pelo aspecto semântico, mas também por marcas de estilo: títulos isentos de metáforas ou outras figuras de linguagem remetem a um texto supostamente sério, acadêmico, científico. Nesse sentido, um título visa a disciplinar o leitor. Vejamos por exemplo essas anotações:

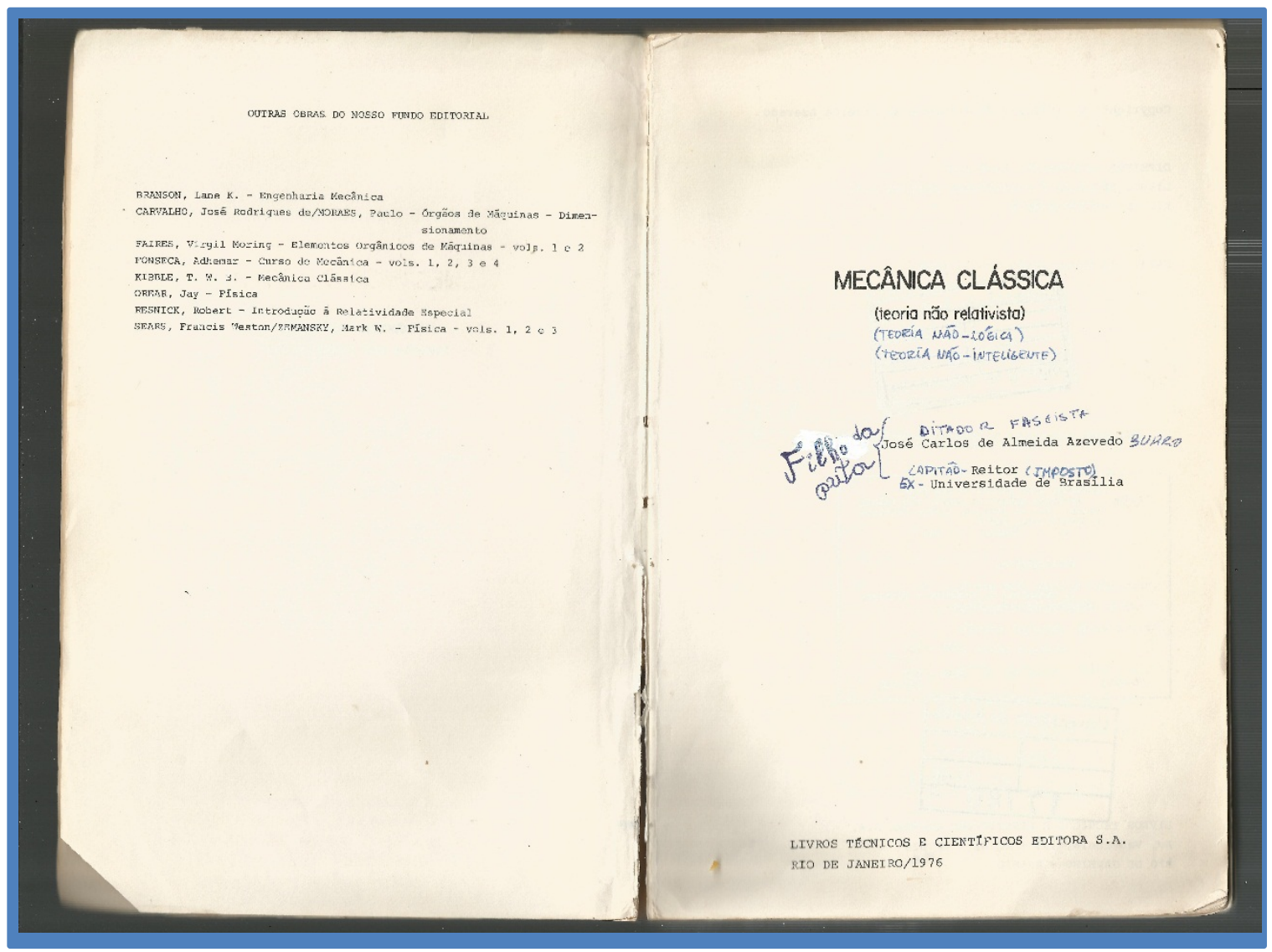

Imagem 1 
As intervenções nesse livro do interventor-reitor da UnB, José Carlos de Almeida Azevedo, são exemplos evidentes do que foi comentado quanto à questão dos elementos paratextuais. Destaque-se que há intervenções diferentes, além da ofensa que revela, por sua vez, o que um dos "rabiscadores" (são letras diferentes) considerava como ofensivo.

O conhecimento científico do reitor é satirizado pela intervenção no subtítulo. Seu papel como reitor é ressignificado como o de ditador fascista. É de se destacar que, oficialmente, Azevedo primeiro entrou na UnB como um professor de física e depois foi nomeado vice-reitor e reitor da universidade. Ou seja: ele faria parte da comunidade acadêmica, na qualidade de cientista. Sua nomeação como vice-reitor, porém, se deu no fim de 1968, no momento mais tenso e intenso de mobilização estudantil. Coincidiu com a exclusão do principal líder estudantil dos quadros da universidade, Honestino Guimarães. Além disso, durante seu longo período como interventor na UnB (de 1968 a 1985), Azevedo nunca escondeu de estudantes e professores seu papel de representante do governo, e mesmo de observador policial dos acontecimentos no campus. Capitão de Mar e Guerra da Marinha, com doutorado MIT (Estados Unidos), sua memória proverbial e tom ameaçador, criou em torno de Azevedo algumas controvérsias: por exemplo, de que ele seria um agente treinado no serviço de informação da Marinha, o CENIMAR. De todo modo, a extensa documentação do SNI na UnB comprova que Azevedo estava em constante contato com a polícia política e que o centro de sua atuação na universidade era o "combate à subversão". As intervenções em seus títulos, nesses rabiscos, criam uma tensão para seu lugar no quadro docente. Explicitam a política oculta na aparente neutralidade dos títulos acadêmicos.

O mais interessante, porém, é a nota sobre a UnB como ex-universidade de Brasília, que ecoa um artigo importantíssimo que, logo no começo da ditadura militar, defendeu a tese de que o projeto original de Darcy Ribeiro e Anísio Teixeira tinha sido destruído (MACHADO NETO, 1967). Não só o nome da universidade é alterado pela intervenção, mas o título do livro se torna citação de um artigo central para o entendimento da história da UnB durante a ditadura. Se a UnB foi uma das universidades 
mais atingidas pela ditadura, o principal motivo era o de que seus criadores eram considerados sujeitos subversivos e perigosos pelo regime.

Destaquem-se ainda as diferenças entre as letras manuscritas. O que indica que foram diferentes os autores das intervenções. Evidentemente, nada sabemos deles além dessas marcas gestuais singulares, que remetem a uma corporalidade ausente das letras mecanicamente impressas. Podemos apenas vislumbrar valores éticos e políticos presentes no teor dessas anotações. Ou seja, elas não são homogêneas, são marcadas pela pluralidade, mesmo que seus agentes sejam invisíveis.

Nas próximas duas imagens, inserções no índice que, entre outros rabiscos, criam novos capítulos para o livro da disciplina de “Estudos de Problemas Brasileiros":

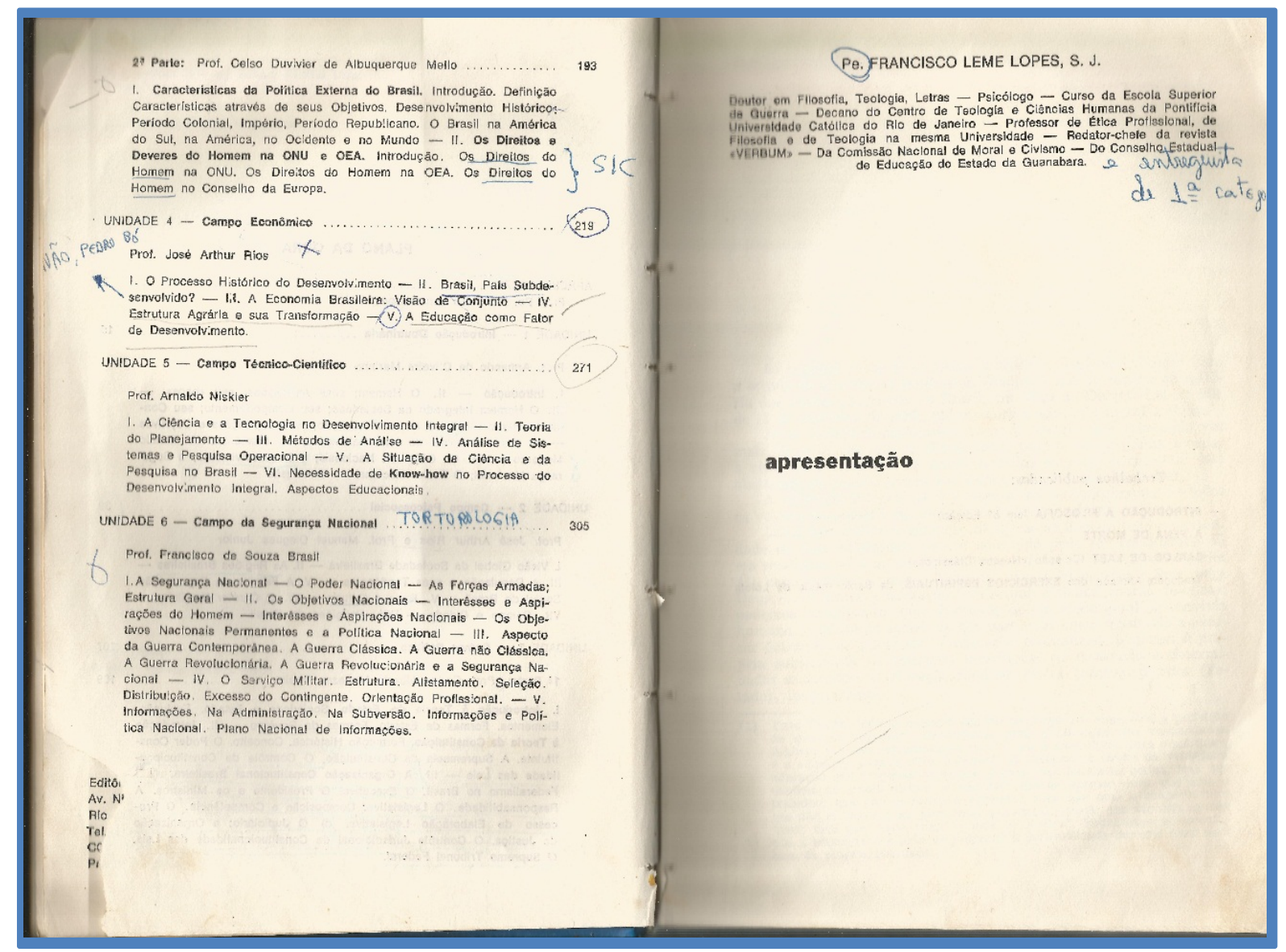

Imagem 2 


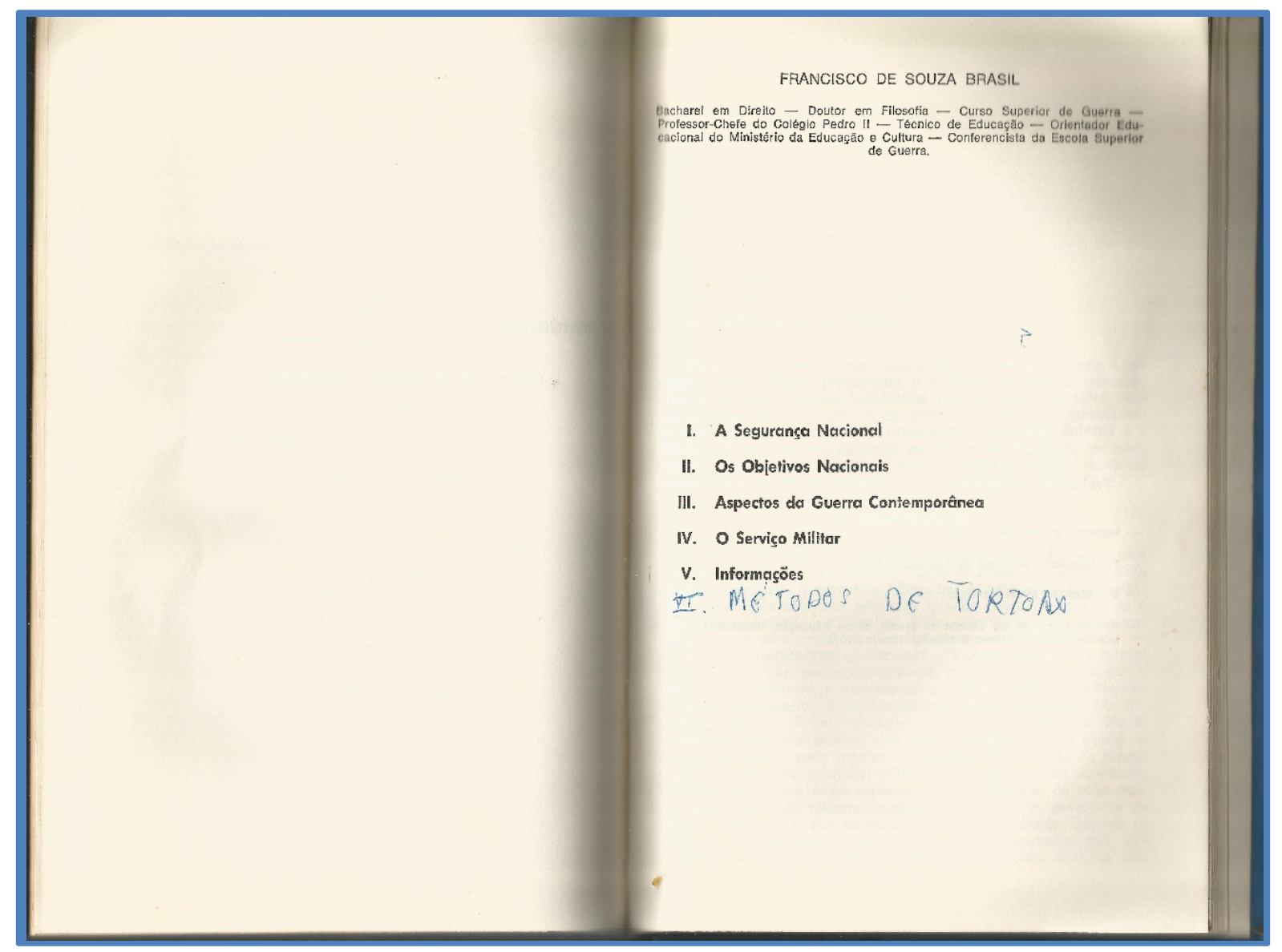

Imagem 3

Os livros mais marcados, com esse tipo de anotação de denúncia ou crítica política, são justamente os de Estudos de Problemas Brasileiros (EPB). Essa disciplina era obrigatória para todos os cursos das universidades públicas, correspondendo à disciplina de Educação Moral e Cívica (EMC). EPB e EMC foram instituídas por decreto no ano de 1969. Seu intuito declarado era formar estudantes patrióticos, imunes à subversão (tanto no sentido moral quanto político). Ou seja: disciplinas que visavam a moldar um tipo de cidadão. A moral, entendida nos termos da preservação da família patriarcal e católica, era vista como base de uma cidadania política "sadia", patriótica. Se tudo funcionasse de acordo com o planejado, o estudante aprenderia as bases da existência moral na formação básica e, já devidamente moralizado, poderia se tornar consciente dos problemas (e soluções) nacionais quando universitário.

Além da questão do conteúdo e do lugar institucional desses livros rabiscados, deve-se destacar aqui a sua forma de circulação. Tratava-se de livros básicos usados em 
Uma vez que os novos capítulos tratariam do tema da tortura. Estamos além mesmo da narrativa dos "porões da ditadura”, uma vez que a tortura é colocada, nesses livros, como parte do funcionamento "normal" das instituições, dos "problemas" e das "soluções" brasileiros. A imagem seguinte é de teor semelhante, com a "lavagem cerebral" incidindo no título do capítulo de livro de EPB:

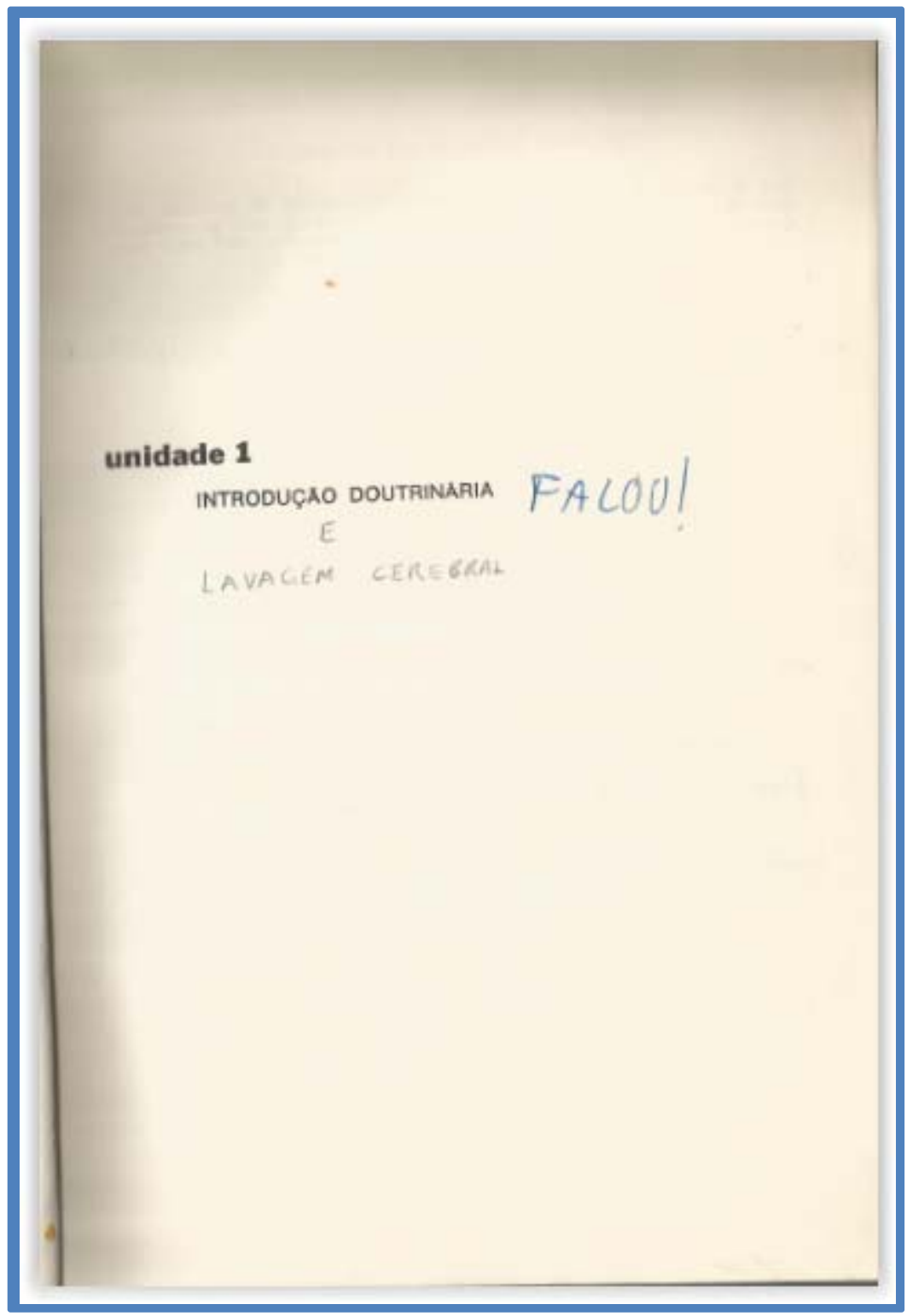

Imagem 4 
Mas aqui a intervenção parece ser seguida a um gesto de apoio, confirmação, incentivo, escrito à caneta e com letra diferente. O leitor, no caso, não se contentou com o assentimento silencioso, a concordância confortável e procurou registrar no livro sua posição. Nesse sentido, a gíria do “falou!”, significando, “está certo”, “é isso mesmo”, ganha nova densidade - exatamente porque o que se rompe aqui é o silêncio.

No ambiente universitário, o silêncio ultrapassava o espaço das bibliotecas, tornando-se verdadeira política institucional, no seu sentido mais amplo. Assembleias eram proibidas. Publicações estudantes, censuradas, perseguidas, motivos de detenções, prisões e torturas. Na UnB, há pelo menos um caso de estudante que foi severamente torturado, basicamente, por expor opiniões críticas em sala de aula. Durante a ditadura, suspeitava-se que em cada sala havia um agente infiltrado (o que, de acordo com a documentação disponível, não estava longe da verdade). Pensar o silêncio como política implica perceber que não se trata apenas da restrição da fala, mas da imposição do aprendizado de quando, onde, com quem e como falar. Ou seja: a fala se torna perigosa e o silenciamento acaba se tornando, da parte dos oprimidos, uma forma de sobrevivência.

A imagem da pessoa que sofreu uma lavagem cerebral é exatamente a do sujeito silencioso, apático, em estado quase vegetativo. Porém, evidentemente, o sujeito que sofreu uma lavagem cerebral bem-sucedida se esquece, inclusive, de que foi vítima da lavagem cerebral. Há, nessas marginalias, um rumor de descontentamento, talvez escondido pelo silêncio que finge ser assentimento, quando é fruto do medo. Algo aparentemente impossível se deixa entrever aí: uma história do silêncio.

A política da fala (e do silêncio) remete também à questão da autoridade - quem é autorizado a falar. Qual fala e de quem é portadora de "verdade". Vejamos as próximas duas imagens, já não em livros de EPB, mas coletâneas de discursos do ditador Médici: 


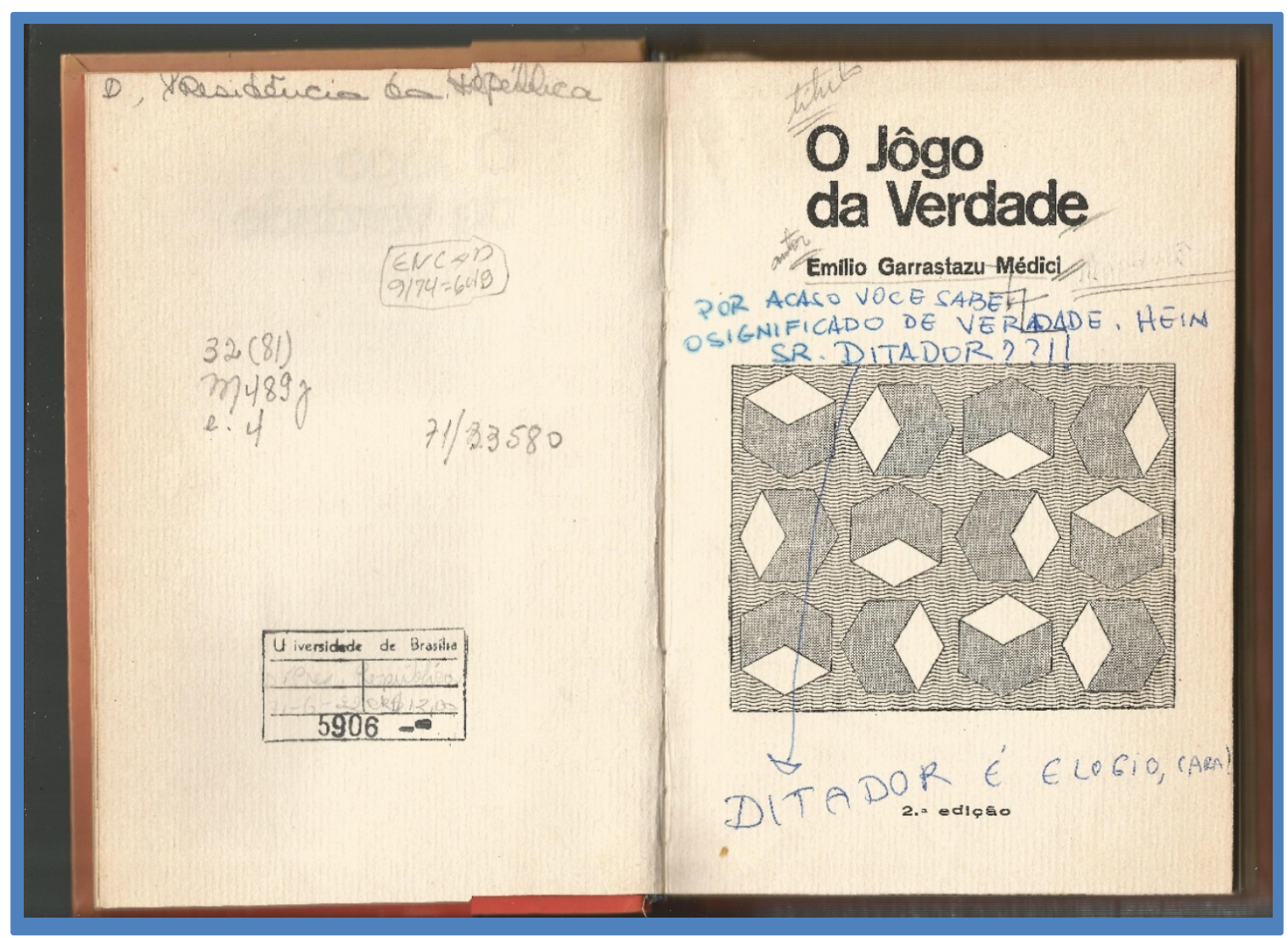

Imagem 5

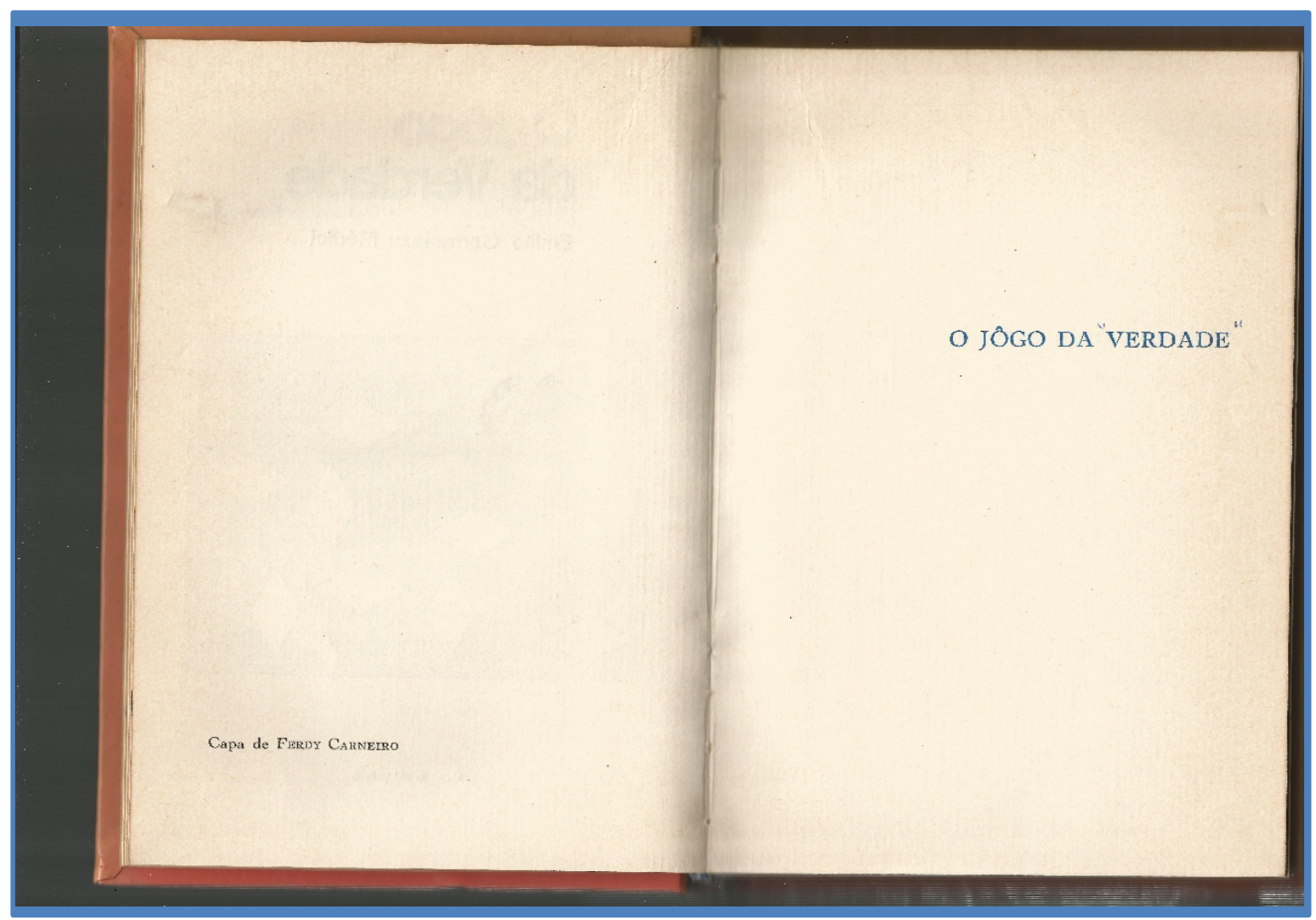


As aspas irônicas são usadas para sublinhar a defasagem de sentido de um certo discurso. As aspas, nesse caso, remetem o conceito destacado a uma fala específica, particular. Com esse gesto, o conceito se torna uma citação, expressão de um lugar determinado, perdendo a aura de universalidade e, mesmo, dependendo do caso, a sua validade. Verdade é uma palavra, "verdade" de acordo com o léxico de um ditador, é outra. No caso do livro rabiscado, o "jogo da verdade" tinha dois sentidos: o do discurso consciente, conhecedor da realidade, mas também a expressão do momento em que as coisas serão definitivamente resolvidas (a "hora da verdade" é também a hora do medo, da violência, em que as pessoas supostamente demonstram sua força, sua coragem ou sua covardia). Em bom português, é a “hora do vamos ver”. Essa interpretação é baseada também no conteúdo dos discursos do livro rabiscado; é o próprio Médici que usa a ideia de "jogo da verdade" nos dois sentidos.

Esse jogo linguístico, porém, só é válido se se supõe que seu autor detém a verdade nos dois sentidos. Ele é portador de uma consciência capaz de decifrar o mundo e, ao mesmo tempo, é o homem forte capaz de encarar as circunstâncias. A questão incluída na primeira imagem apresentada, "por acaso você sabe o significado de verdade, sr. Ditador?", coloca esses pressupostos em xeque. Além disso, dirige-se diretamente ao autor dos discursos, como se ele fosse um interlocutor - em tom de desafio. Isso, em que pese o fato de que as aspas irônicas cobrindo a palavra "verdade" são mais econômicas e têm um efeito semelhante.

Nas próximas duas imagens, intervenções em outro livro - um texto marcado pela dimensão de propaganda da Guerra Fria, doação da "Casa Thomas Jefferson" à UnB: 


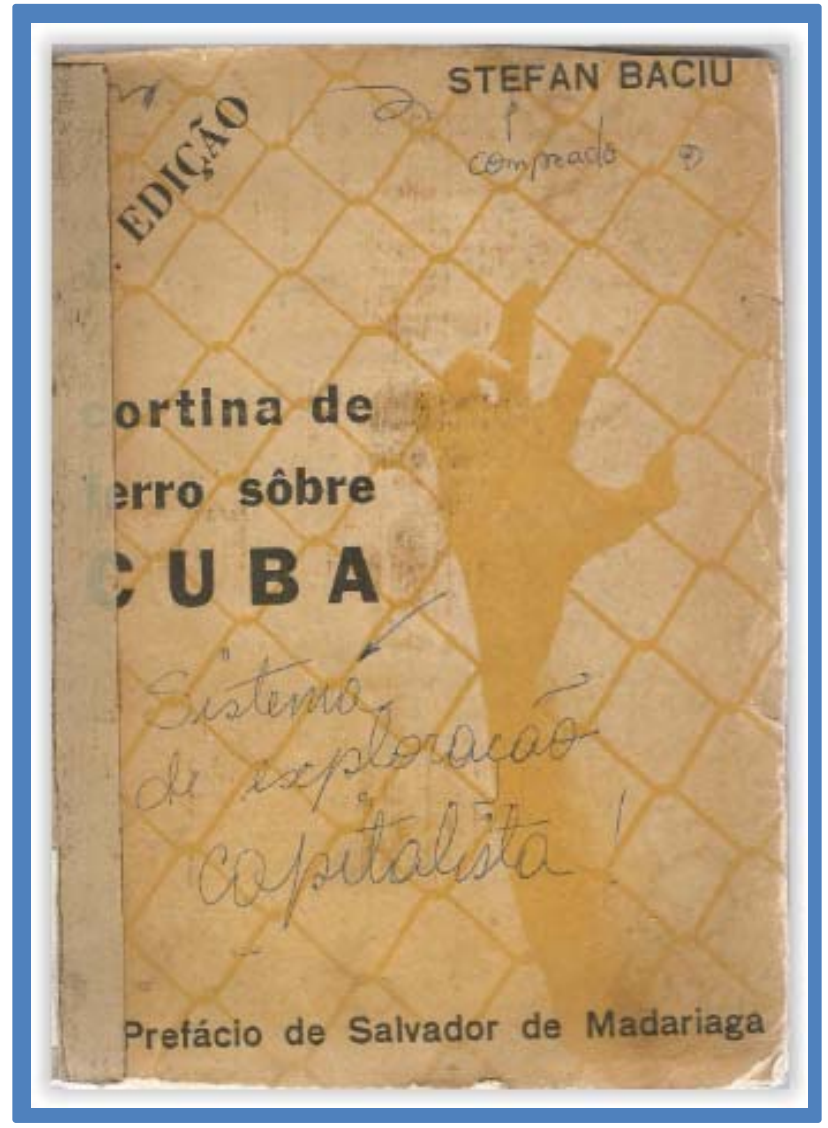

Imagem 7

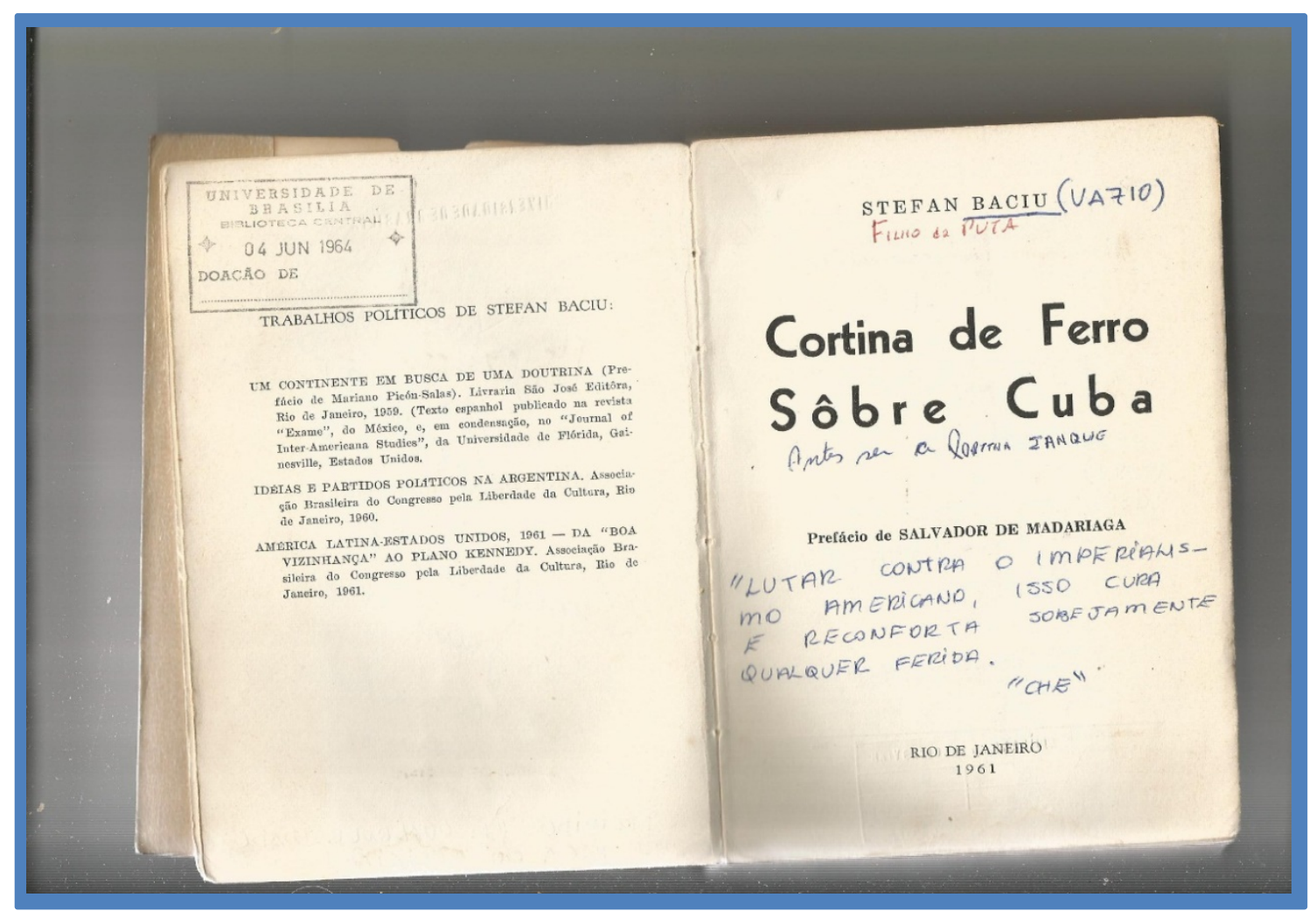

Imagem 8 
O chiste baseado na assonância do nome - tática de derrisão cujas origens remontam à noite dos tempos. Baciu se torna Vazio. A intervenção na capa cria uma polarização entre título e imagem. As mãos segurando uma cerca, de acordo com o projeto editorial inicial, são ícones da "cortina de ferro" - em síntese, do povo cubano preso atrás dessa cortina. Alguém, porém, desenhou uma seta ligando a mão à expressão “sistema de exploração capitalista”. Evidentemente, não há como se saber as intenções do autor dessa intervenção. O que não se limita às marginalias, é parte de todo e qualquer trabalho de interpretação. O que acontece é que nas marginalias não temos nem mesmo elementos contextuais suficientes para estabilizar as interpretações ou criar uma ilusão de transparência. O anonimato e o fato de não podermos datar as intervenções, se não aproximadamente, geram uma forte instabilidade de sentido. Daí a eclosão de camadas de novos sentidos possíveis. O discurso da capa do livro, que tende ao monológico, tornase polifônico. O leitor que pega o livro depois da intervenção é convidado a novas interpretações, como se tivesse em mãos um texto rasurado, um texto revisto e alterado, mas em que as diferentes versões são preservadas, como num palimpsesto. Por exemplo, as cercas podem ser ressignificadas, de “cortina de ferro" para “exploração capitalista”. Mas as mãos também: não seriam garras?

\subsection{Intervenções textuais}

Essas intervenções, não incidindo sobre os elementos para-textuais, são, basicamente, de dois tipos: revisões e alterações dos textos dos livros e redação de novos textos, geralmente aproveitando os espaços em branco das páginas. Questões já comentadas retornam. Como, por exemplo, a questão da política do silêncio. O paradoxo é que os livros, propostos a seus leitores como dispositivos do assentimento e da leitura silenciosa, tornem-se espécies de fóruns - lembrando que a sala de aula não cumpria esse papel; quando não eram os próprios professores afinados com a ditadura, agentes infiltrados se encarregavam de vigiar e controlar as opiniões. Mais ainda: mesmo na ausência física desses agentes, a legislação se encarregava de transformar a crítica e mesmo a mera fala em crime. O conhecido decreto 477, adendo ao Al-5, previa, por exemplo: 
Art $1^{0}$ Comete infração disciplinar o professor, aluno, funcionário ou empregado de estabelecimento de ensino público ou particular que: I - Alicie ou incite a deflagração de movimento que tenha por finalidade a paralização de atividade escolar ou participe nesse movimento; III - Pratique atos destinados à organização de movimentos subversivos, passeatas, desfiles ou comícios não autorizados, ou dele participe; IV - Conduza ou realiza, confeccione, imprima, tenha em depósito, distribua material subversivo de qualquer natureza; VI - Use dependência ou recinto escolar para fins de subversão ou para praticar ato contrário à moral ou à ordem pública.

Passemos às intervenções textuais. Aqui, novamente, num livro de EPB:

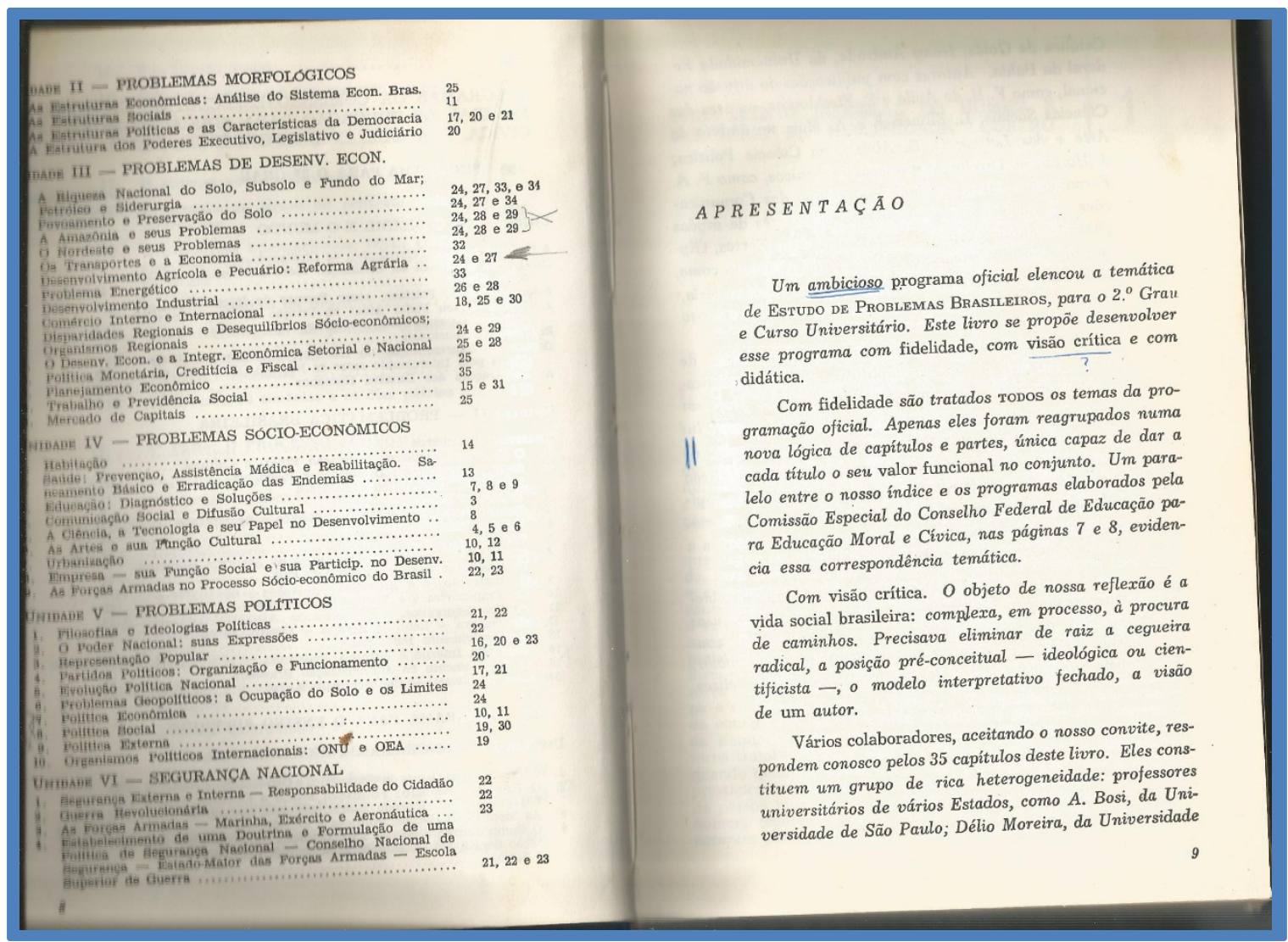

Imagem 9

Note-se que os sublinhados, as interrogações criam uma espécie de segunda voz no texto. Como a pontuação de um texto tem sentido semântico, esse tipo de rabisco interfere no significado. Mas também incide na enunciação - por exemplo, enfatizando uma afirmação que "distorce" o sentido original do texto. A palavra "ambicioso" é duplamente sublinhada - portanto, não só sendo destacada, mas também enfatizada. 

poucas linhas a seguir, a expressão "visão crítica" também é sublinhada - dessa vez com o ponto de interrogação.

Sobre esse tipo de intervenção textual, vale recordar que, de acordo com Flusser (2010, p. 97), o papel da lei, no mundo contemporâneo, vem sendo despolitizado e convertido no do manual de instruções. Num contexto despolitizado (como o de uma ditadura) não haveria mais a ideia do dever ou do princípio abstrato, e sim a da funcionalidade. De acordo com Flusser, nesse campo da funcionalidade, uma lei como “honra teu pai e mãe" torna-se a instrução de uso "se você quiser tomar uma canja de galinha, então comporte-se assim e assado com uma lata de sopa em conserva”.

Ainda segundo Flusser (2010, p. 140), haveria três tipos de forma de decifrar um texto: comentar, obedecer e criticar. O comentário é pensar com, colaborar com o sentido do texto. Obedecer é seguir o texto como um manual de instruções. Na crítica, o leitor se torna uma espécie de detetive ou um assassino, na medida em que a crítica procura polemicamente o crime cometido pelo texto - ou é considerada, ela mesma, um crime contra o texto. Embora a discussão de Flusser não se refira particularmente a um contexto ditatorial, é de se observar que o ideal de estudante "moralizado" e “consciente dos problemas brasileiros" era o de um sujeito despolitizado, silenciado, devotado à recepção passiva das instruções advindas dos mestres. Criticar, nesse espectro político, não se confundia com discordar ou refletir sobre: era entendido como questionar e desqualificar a autoridade. Não, evidentemente, que essa prática autoritária se limite a uma situação ditatorial - é apenas exacerbada e instrumentalizada pelo governo que pretende criminalizar todo dissenso.

O leitor que inscreve suas opiniões no texto desfaz a imagem equivocada do receptor passivo. Explicita que a leitura é um ato. Ao escrever seus próprios textos no livro, o leitor se torna também uma figura de autor. Por um lado, o lugar de autoridade do autor é profanado por esse gesto. Por outro, o leitor, no sentido forte da expressão, toma a palavra para si. 


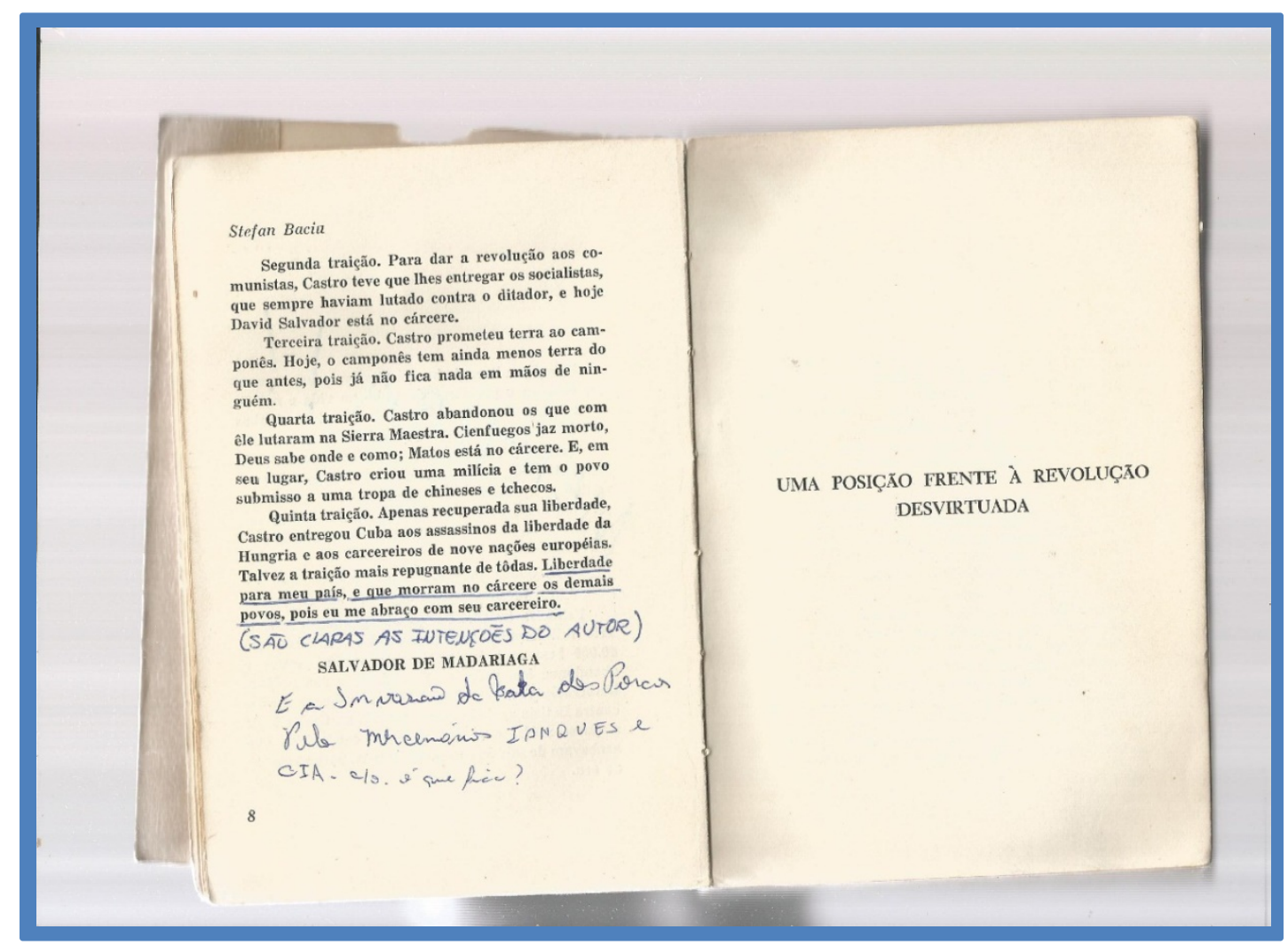

Imagem 10

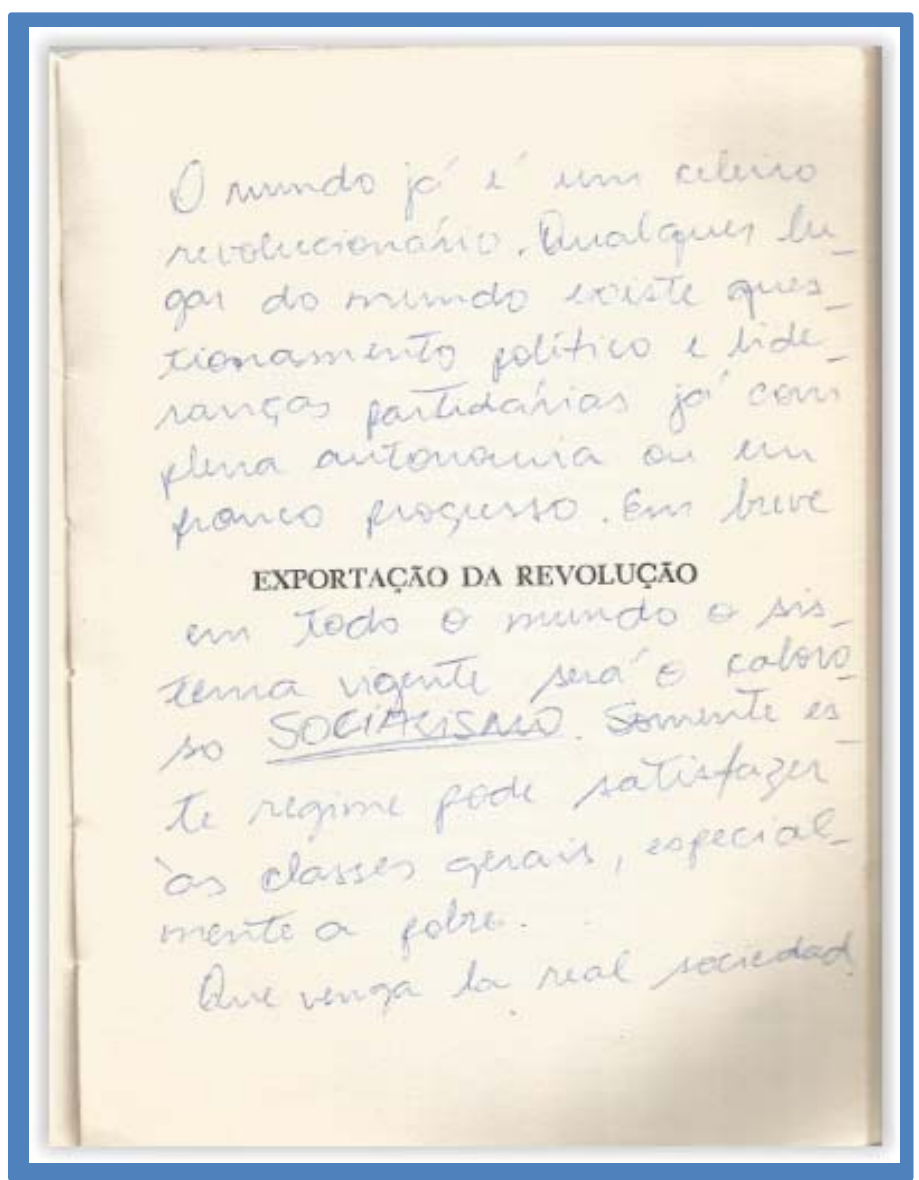

Imagem 11 
Paisagem de cacos e dores revoltadas: as marginalias da ditadura em livros de uma biblioteca universitária Daniel Barbosa Andrade de Faria

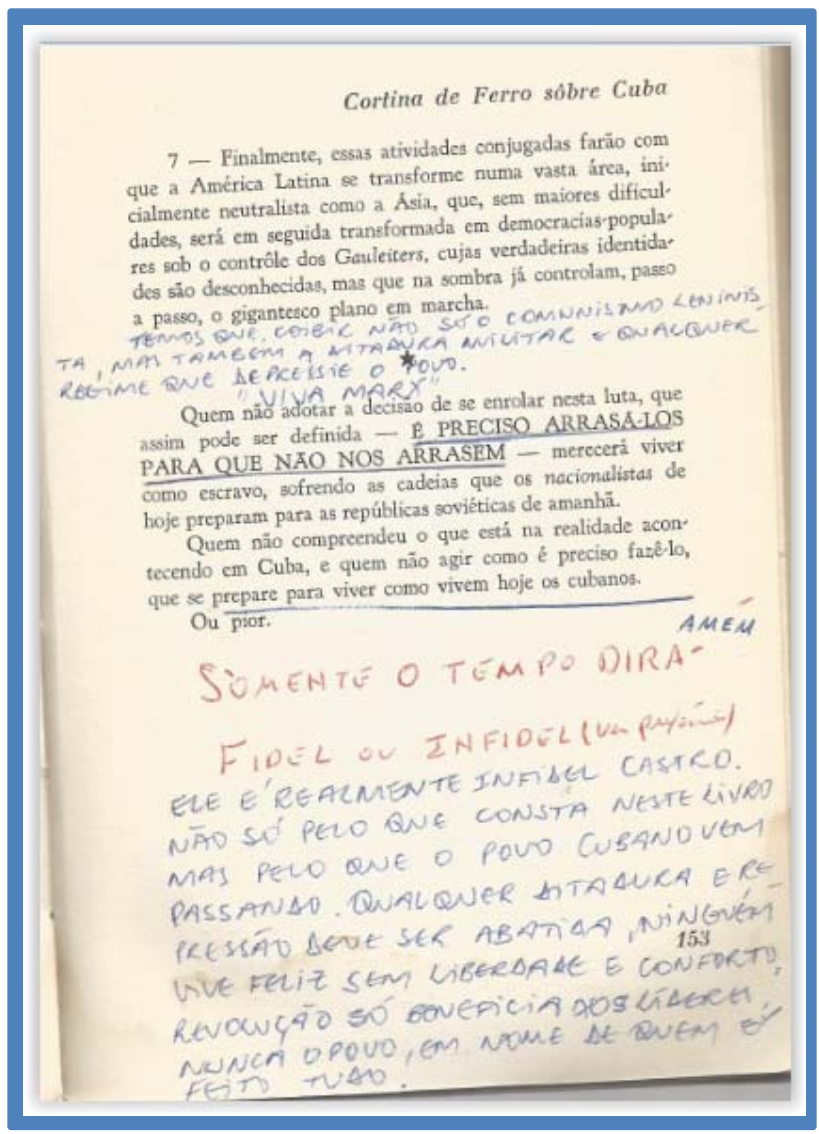

Imagem 12

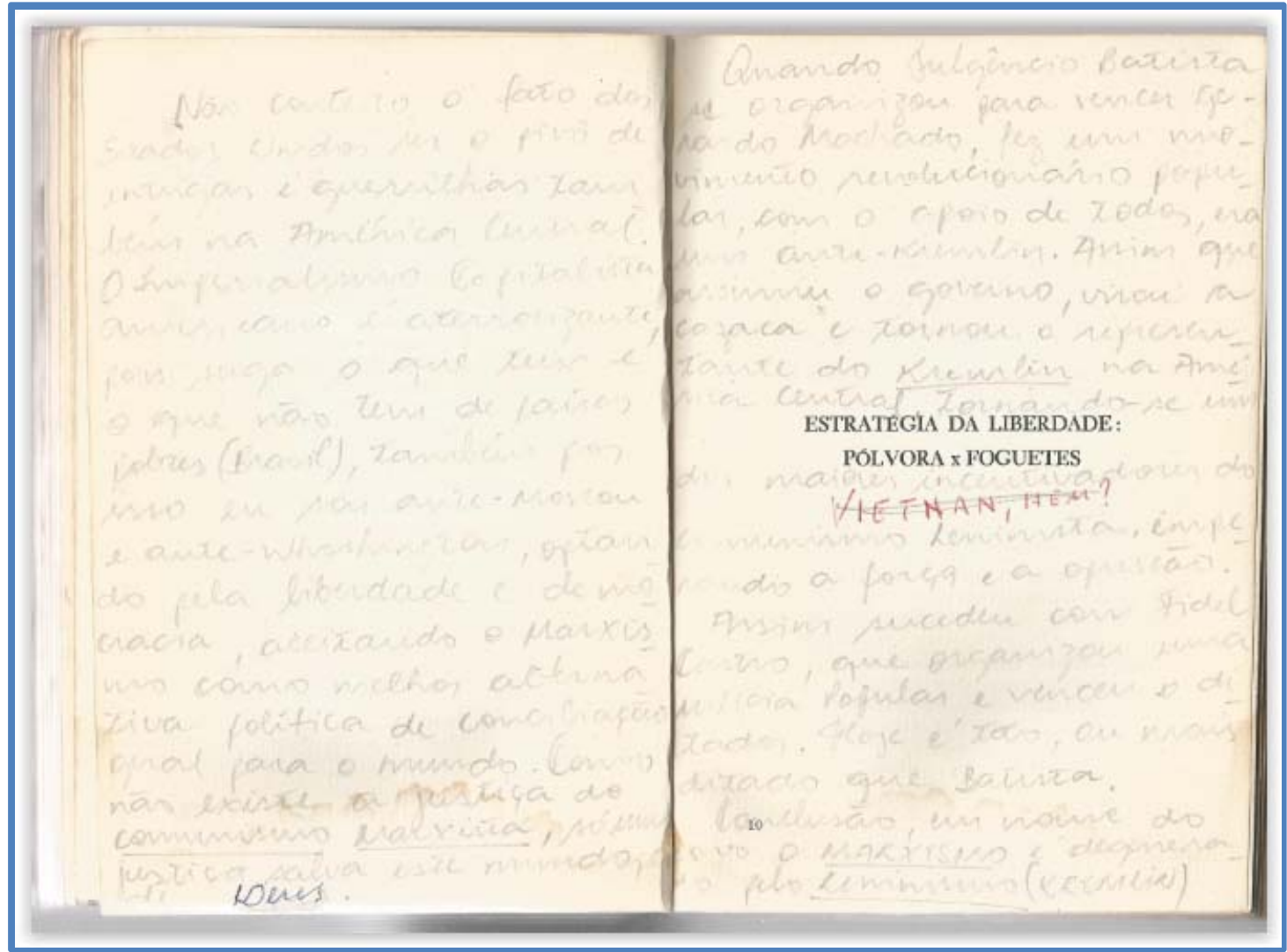

Imagens 13 
Letras diferentes, com cores diferentes, umas a lápis, outras à caneta. A primeira impressão dessas páginas é a de que elas se tornam mosaicos, multicoloridos - não necessariamente belos, ao menos no sentido clássico da beleza. Alguém escreve um longo comentário sobre o tema do livro, outro alguém intervém nesse comentário, com uma resposta ou uma outra consideração. O texto impresso é marcado pela homogeneidade das letras, pelo seu aspecto de produto técnico, impessoal. No limite, impressões maquinais em tinta preta sobre o espaço branco do papel, remetendo à reprodutibilidade dos discursos, seu controle por um aparato econômico e político editorial. Pelo contraste, o manuscrito nessa situação parece anacrônico, amador, espontâneo. Não é um texto que vai ser indefinidamente reproduzido, mas um gesto traçado num instante que não vai se repetir. A marca de uma experiência singular com aquele livro num dado momento. O fato de ser anônimo, portanto, não implica ser impessoal (daí, talvez, a já comentada utopia de Blanchot com uma escrita simultaneamente horizontal, destituída de autor e plural, heterogênea).

As opiniões também variam. Algumas mesmo indo contra as ortodoxias dos movimentos organizados de esquerda que se opunham mais frontalmente à ditadura. Segundo um dos anônimos, uma coisa é o marxismo, outra a revolução cubana. $O$ leninismo é uma deturpação do sentido revolucionário do marxismo. A revolução ainda está por vir. Outro afirma que Fidel é mesmo o traidor do povo cubano, respondendo a uma questão anterior sobre se Fidel seria ou não "Infidel". Um terceiro afirma que a ditadura militar precisa ser derrubada pelo povo, tanto quanto a cubana. Outro, por fim, faz uma apologia à revolução, avisando que “o mundo já é um celeiro revolucionário". À caneta, duas inserções que praticamente rompem qualquer pretensão de interpretação, apesar de serem impregnadas de sentidos possíveis: em azul, a palavra Deus; em vermelho, Vietnã.

\subsection{Intervenções editoriais}

Há intervenções que poderíamos chamar de editoriais. O editor é o mediador entre escritor e leitor. É nessa mediação que se constitui, porém, a instituição da autoria. Ou seja: o editor pode tender ao invisível, mas é parte integrante da produção midiática do livro. O editor seleciona. Também corrige, altera o texto, segundo o que a editoria 
considera ser necessário para a disposição do texto para o público leitor. Daí que a marca editorial adquira também uma aura de valor, de "selo de qualidade" daquilo que está sendo apresentado.

De modo geral, várias das intervenções já apresentadas podem ser lidas como transformação dos leitores em editores. Eles alteram o texto, explicitando alguns de seus aspectos para leitores futuros. Em particular, essas marginalias são marcadas pelo fato de que não são marcações que um leitor faz para si mesmo (por exemplo, alguém que sublinha um texto como apoio mnemônico, ou faz anotações para um uso posterior). Ao contrário, por seu intuito polêmico, crítico e profanador elas se destinam a outros usuários que viriam e virão a tomar os livros rabiscados em mãos. Não se trata, portanto, de uso privado e sim de circulação pública de ideias, embora necessariamente (devido ao contexto ditatorial) clandestina. Clandestina, mas paradoxalmente inscrita no próprio material de formação cultural da ditadura, passando-se dentro de um dos recintos mais vigiados da universidade - a biblioteca. O gesto editorial dessas marginalias remete, assim, a seu sentido eminentemente político.

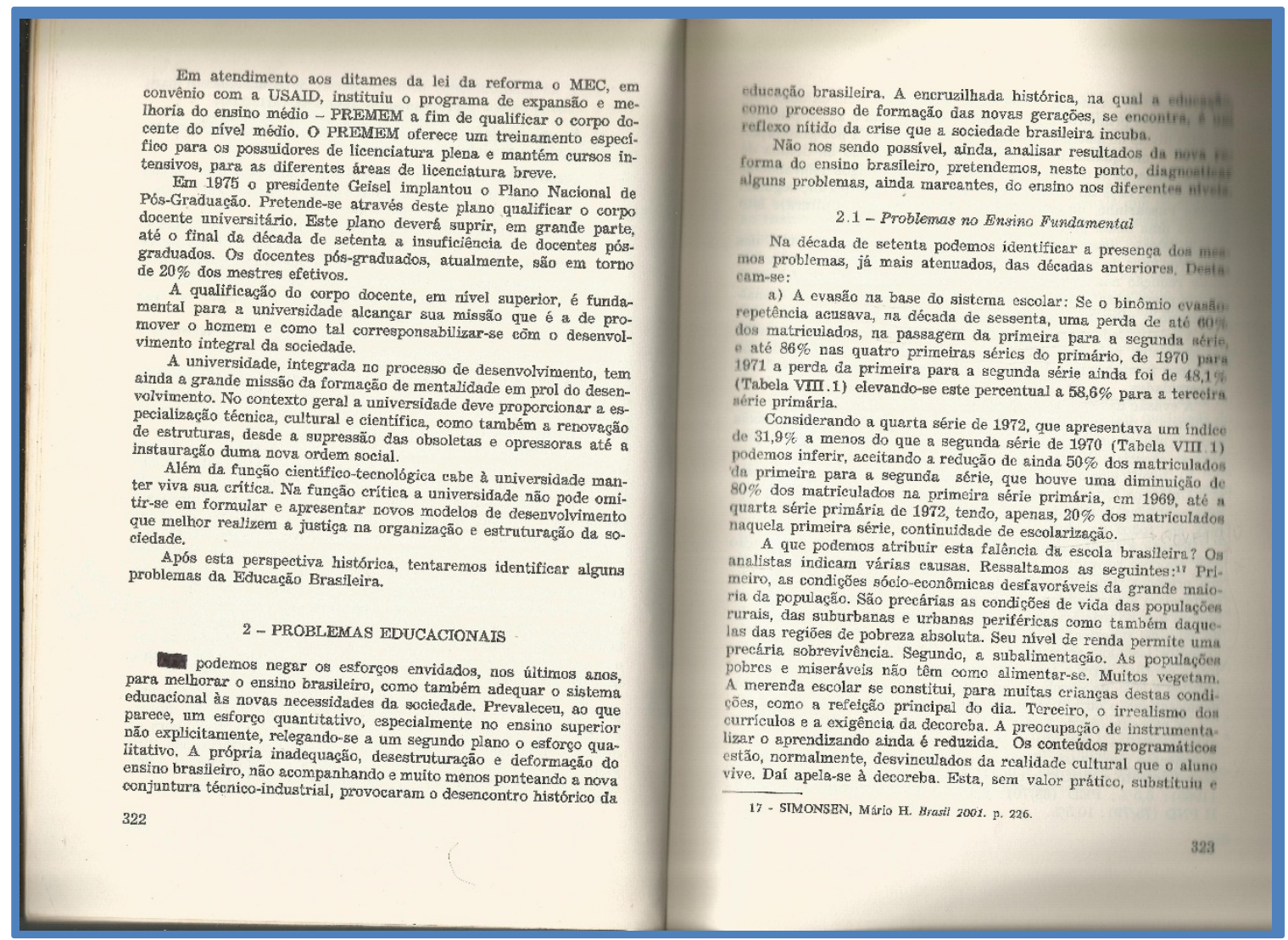

Imagem 14 
A intervenção na imagem anterior é simples, sutil, apenas um retângulo preto cobrindo a palavra "não". A interdição do "não", no caso, era a própria interdição da liberdade e do pensar. Não há sentido numa ideia de liberdade que pressupõe, sempre, o "sim". A frase corrigida pelo editor anônimo era, originalmente: "Não podemos negar os esforços envidados nos últimos anos"; passando a ser um simples: "Podemos negar...."

A dupla negação, “não podemos negar”, quase uma exposição didática do princípio do silenciamento, da imposição do silêncio - uma vez que no texto nem sequer se afirma algo, apenas se interdita uma possível negação - recebe uma terceira negação, esta a do quadriculado negro sobre a palavra não. Podemos negar, por sua vez, é afirmação de algo: o poder de dizer não - e também o direito de o dizer.

Num sentido mais relacionado às práticas educacionais, há, por fim, mais uma inversão embutida nessa e em outras práticas editoriais. Aqui, é o aprendiz que corrige a autoridade.

Novamente, uma marca no livro de Baciu:

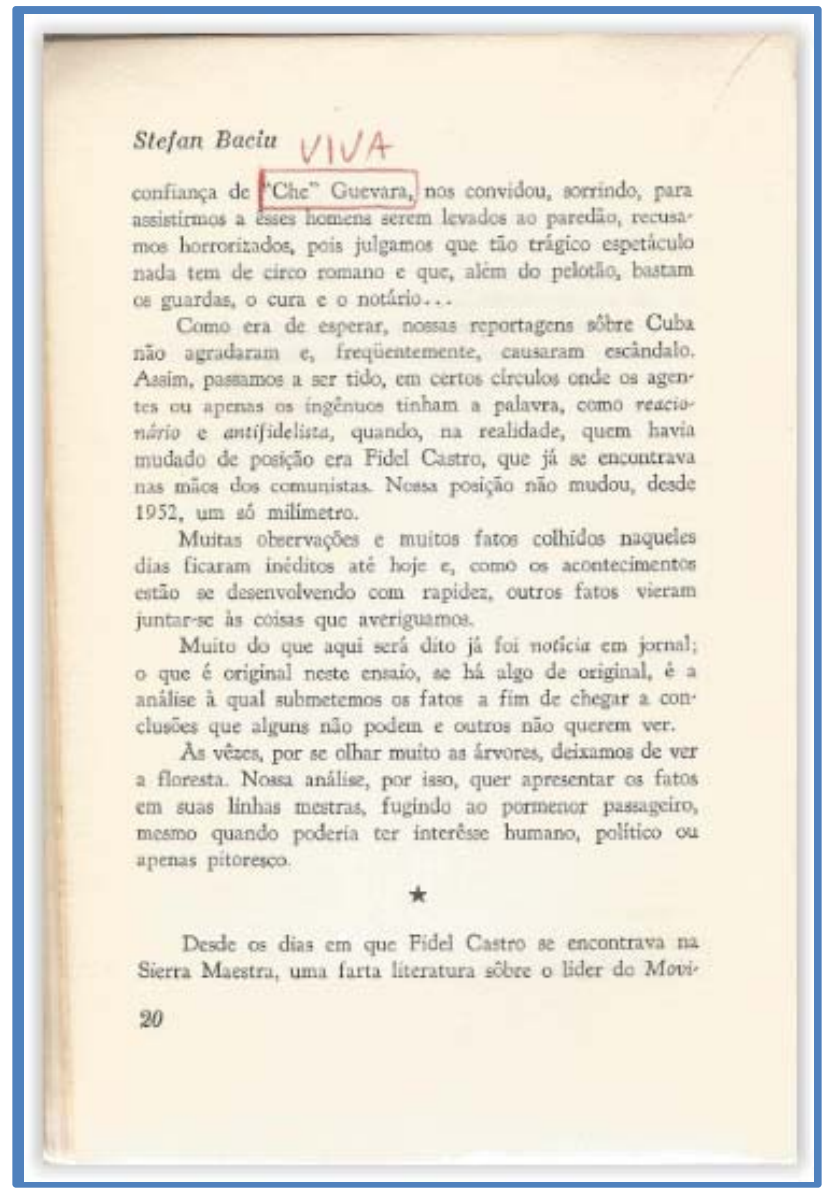

Imagem 15 
Não é preciso repetir aqui, aspectos já considerados em outras intervenções. Observe-se, contudo, a economia do traço, remetendo a um gesto. A expressão "VIVA" prescinde de exclamação para se mostrar como efeito de uma paixão - expressividade acentuada pelo evidente simbolismo da cor vermelha. À primeira vista, sobre um texto apresentado de forma impessoal e acadêmica, irrompe uma paixão. Paixão essa que inverte o sentido do texto acadêmico.

Só não se pode perder de vista que essa ideia de uma paixão que irrompe também é um efeito midiático. A caneta e a cor vermelha não são menos artefatos do que o texto impresso. O que temos, assim, é mais efeito de sinceridade, que funciona devido ao contraste entre texto manuscrito e palavra impressa. O que seria da aparência da espontaneidade, impressa na gestualidade do manuscrito, por exemplo, se não passasse, exatamente, por esse parecer ser? O humano que retorna, no espaço midiático, já é um espectro: estando além de sua ausência e depois de sua morte (GROYS, 2012, p. 64). Por isso, essa parte se encerra com uma intervenção editorial de um anônimo, mas dessa vez não sobre o texto impresso e sim sobre o comentário manuscrito de outro anônimo:

“Colha um verso no jardim da poesia".

“Muito bonito, mas não é momento para isso",

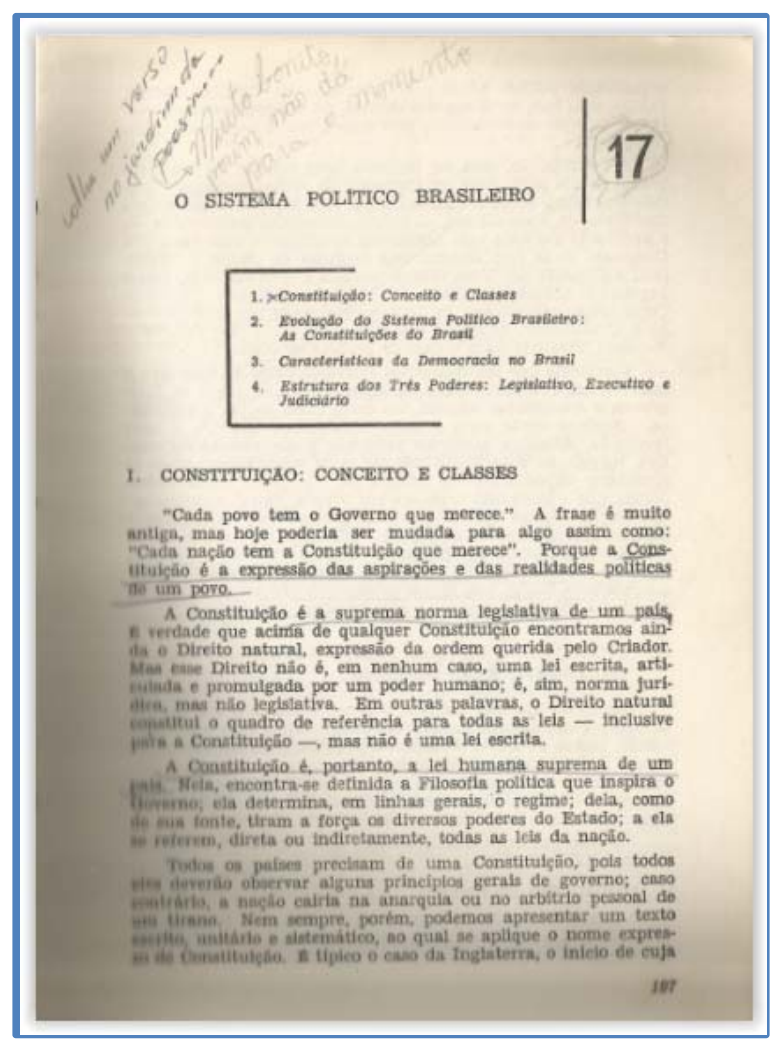

Imagem 16 


\subsection{A reclassificação dos livros: a categoria da suástica}

O símbolo mais presente nas intervenções aqui estudadas é a suástica. Nos livros de discursos de Médici, em particular. Esses livros estão localizados, atualmente, na prateleira de Brasil - Ciência Política. Também há muitas suásticas em livros de Alfredo Buzaid, ministro da Justiça do governo Médici - estes, colocados na prateleira de Direito Constitucional. Os volumes do Inquérito Policial-Militar "O comunismo no Brasil", realizado em 1966, sob a direção do General Ferdinando de Carvalho, também estão marcados por suásticas. O lugar desses volumes, na Biblioteca, é na coleção da Biblioteca do Exército, sob o assunto Ditadura - Ditadores. Outro livro repleto de suásticas é $O$ processo revolucionário brasileiro (BRASIL. PRESIDÊNCIA, 1969), editado pela Assessoria Especial de Relações Públicas, em comemoração aos cinco anos de aniversário do golpe de 1964 (destacaram-se aqui, nas imagens, os capítulos sob autoria de Meira Mattos e Gilberto Freyre). O mesmo acontece com o livro de Edgar Hoover sobre o comunismo. Por fim, também há suásticas em livros de Estudos de Problemas Brasileiros, que contavam com uma classificação exclusiva para a temática de EPB.

A suástica tinha e tem um evidente sentido emblemático, relacionado ao nazismo, ao extermínio e aos horrores do século XX. Assim, era uma forma econômica e direta de comunicação crítica sobre o teor dos livros assim marcados. Destacaram-se aqui as classificações dos livros de acordo com o sistema oficial da biblioteca, para sugerir que se criou, com as suásticas, uma categoria paralela, extraoficial: a dos livros com teor nazista. Nessa constelação, outros símbolos por vezes aparecem: a sigla do FBI, da CIA ou da Klu Klux Klan, associando-se a suástica (e o nazismo) ao racismo e à polícia dos Estados Unidos.

Por seu caráter de emblema, a suástica funciona como uma espécie de marca, de ícone do conteúdo dos livros - paralelamente, por exemplo, à marca da editora ou carimbos indicativos da procedência dos livros. Como sinal gráfico, a suástica também acaba cumprindo papéis de ilustração, na contracapa ou mesmo na capa dos livros.

Os próximos dois exemplos estão em livros do ditador Médici: 


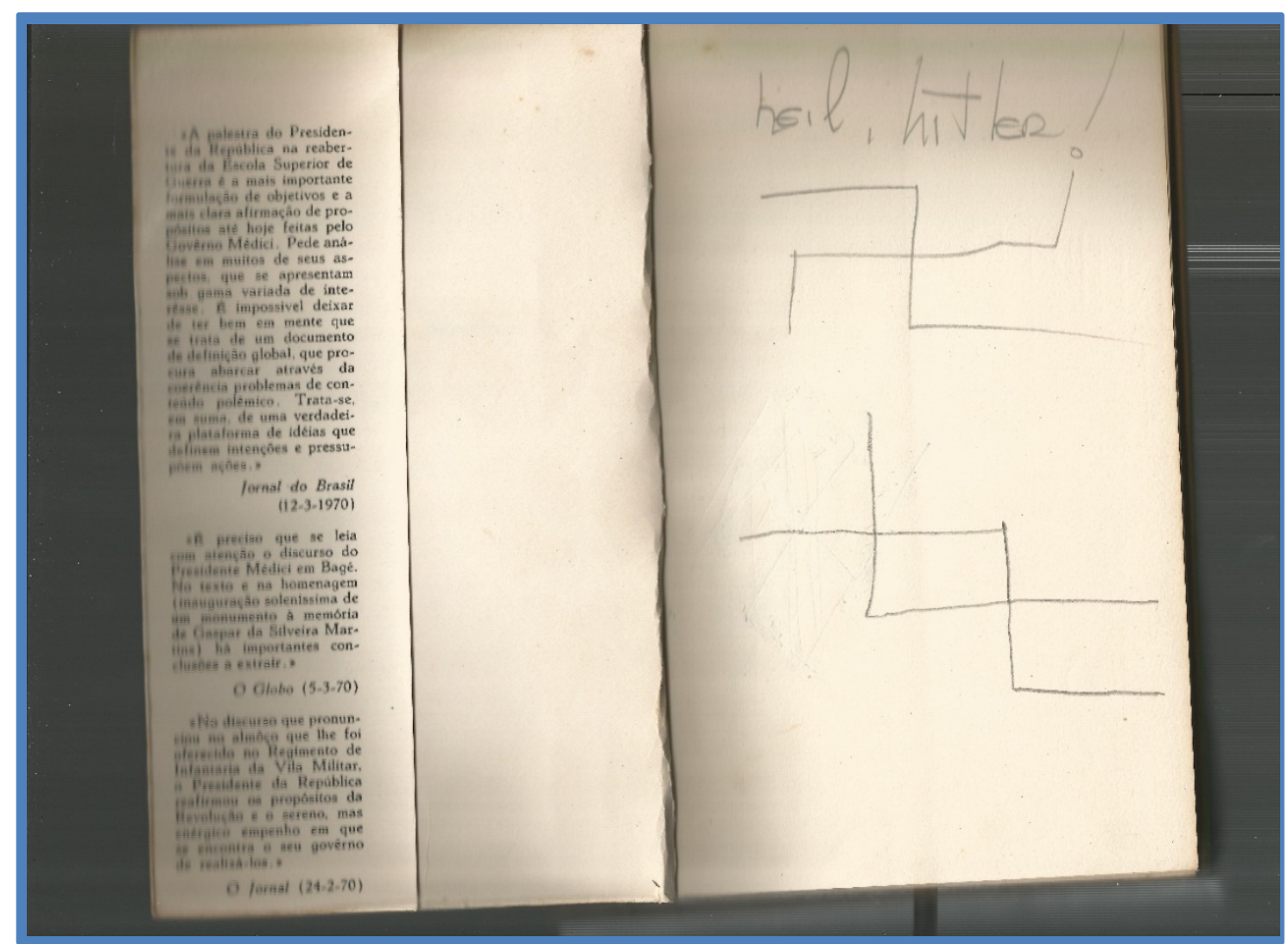

Imagem 17

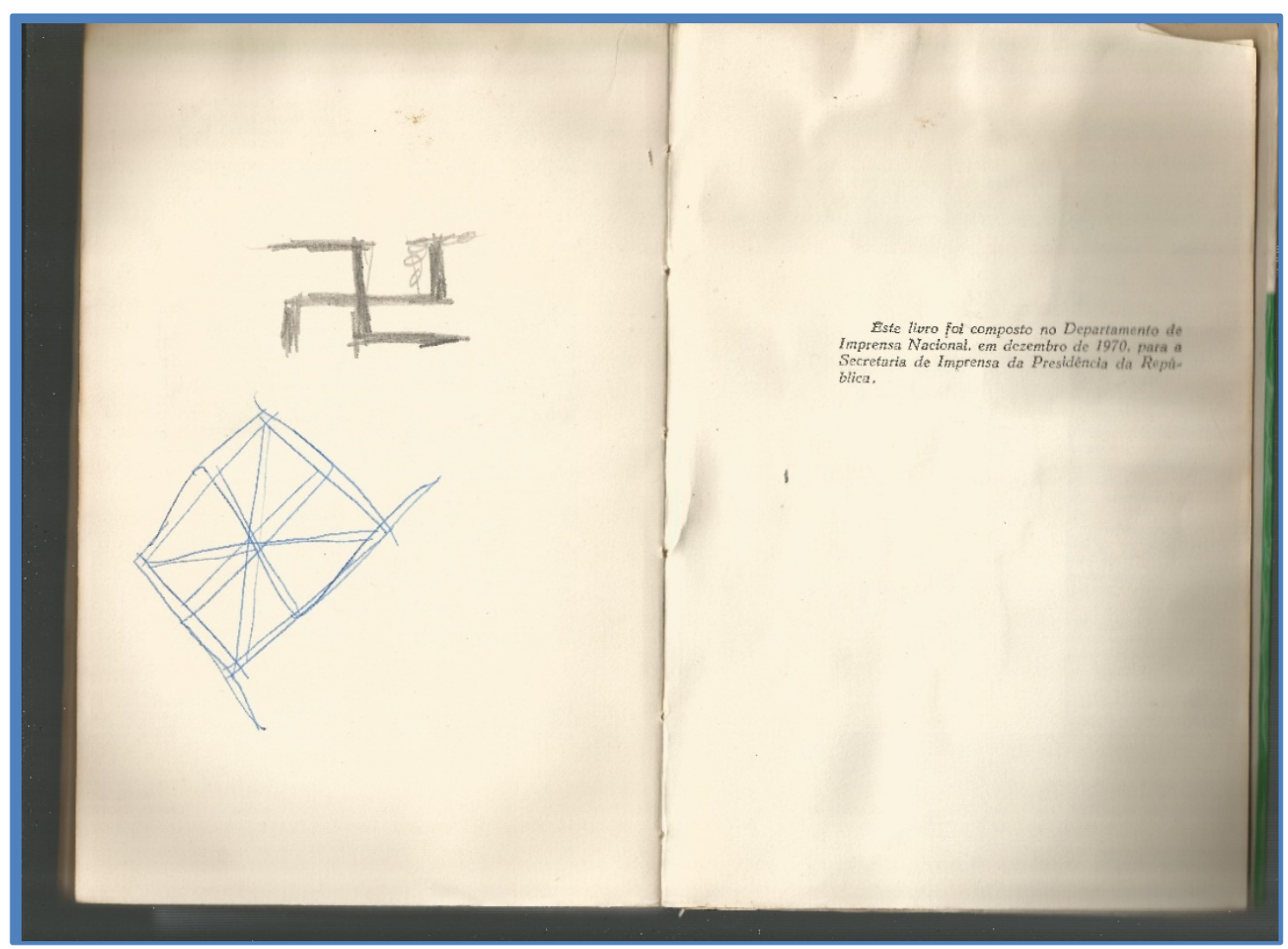

Imagens 18 
Nesses casos, em alguns momentos, os rabiscos parecem parodiar o padrão geométrico das capas dos livros: cubos, quadrados, linhas retas em verde e amarelo. Nessas capas, a mensagem redundante é a da regularidade, da racionalidade do patriotismo. Nos rabiscos, o cubo e suas linhas entrecruzadas vão se entrelaçando, caminhando para a "possibilidade da suástica" que se configura em seguida. Ao que parece, porém, a ideia é mais explicitar o implícito do que mudar o sentido da imagem. De qualquer modo, depois dessa intervenção, os cubos das capas de livros de Médici passam a ter uma suástica implícita. A imagem linear da modernização, por sua vez, ganha outras dimensões, como a do "eterno retorno", no sentido negativo da repetição do mesmo: o horror que retorna.

Os padrões gráficos das capas dos livros de Médici, com suas linhas retas e cubos em verde-amarelo, são caracterizados pelos sentidos de precisão, ordem, controle técnico e patriotismo. Na extensa bibliografia sobre a ditadura, apresenta-se com frequência a temática da ditadura como "modernização conservadora” (PATTO SÁ, 2014), como governo orientado por duas matrizes ideológicas: o fetiche da técnica, da industrialização, da administração racional da população e do território, por um lado; por outro, e complementarmente, a valorização da moral patriarcal, das hierarquias e do catolicismo.

Escapa ao horizonte desse artigo aprofundar essa questão, mas deve-se observar que a aproximação entre as formas geométricas e a vitória da razão, não somente no campo das ciências ou do trabalho, mas também no da política, tem profundas repercussões na modernidade (STAROBINSKI, 1988). Os símbolos geométricos adquiriram o sentido (imaginário) de encarnação da própria razão técnica. Como se eles falassem por si sós, prescindindo de qualquer outra construção de sentido - ou mesmo do trabalho de interpretação. Signos pretensamente evidentes por si mesmos, implicando modernidade. Em verde-amarelo, devidamente revestidos de aspectos patrióticos.

Na imagem que vimos acima, a inserção da suástica provém do desdobramento do próprio grafismo presente nas capas dos livros de Médici. As linhas que unem os cubos vão se desdobrando, até sugerirem a forma da suástica. Com isso, o grafismo da técnica e 
da razão deriva para a forma do emblema político. A geometria que sugeria o império da técnica passa a significar uma outra coisa: uma experiência histórica e política concreta, a do nazismo.

A imagem a seguir é de um dos livros de Alfredo Buzaid:

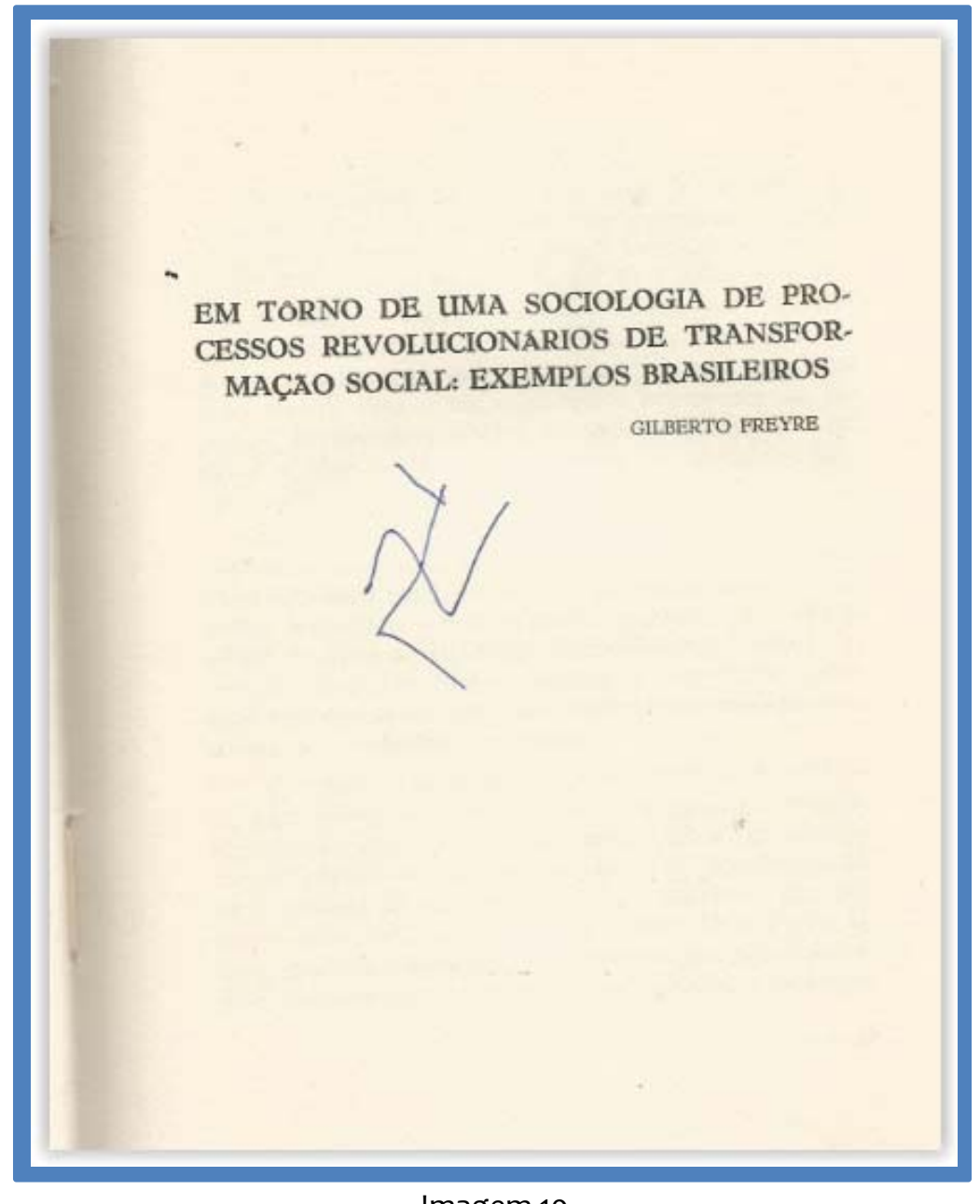

Imagem 19

Aqui a do Inquérito Policial-Militar citado - com o detalhe, significativo, de que a palavra "exército" é destacada por um quadriculado que pode ser visto, ao mesmo tempo, como base de um emblema com a suástica, como se fosse mesmo um brasão clandestino do exército brasileiro: 


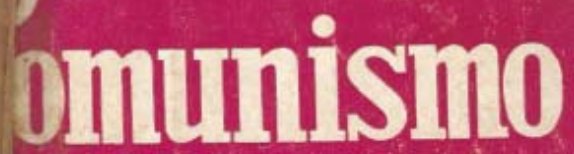

JERTO POLICIAL MILITAR Nं은 709

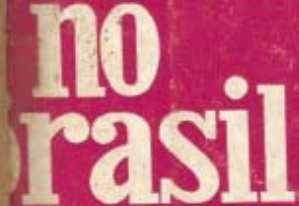

I- $\mathbf{A}$ CONSTRUCÃO

II-A INFILTR ẢCĀ̃O

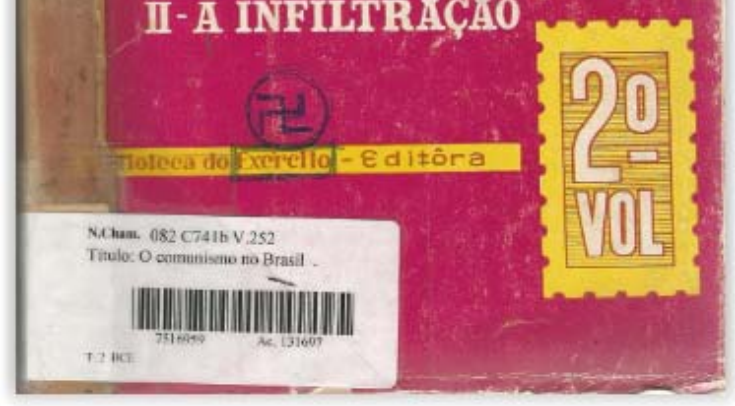

Imagem 20

A seguir, os dois capítulos do livro O processo revolucionário brasileiro:

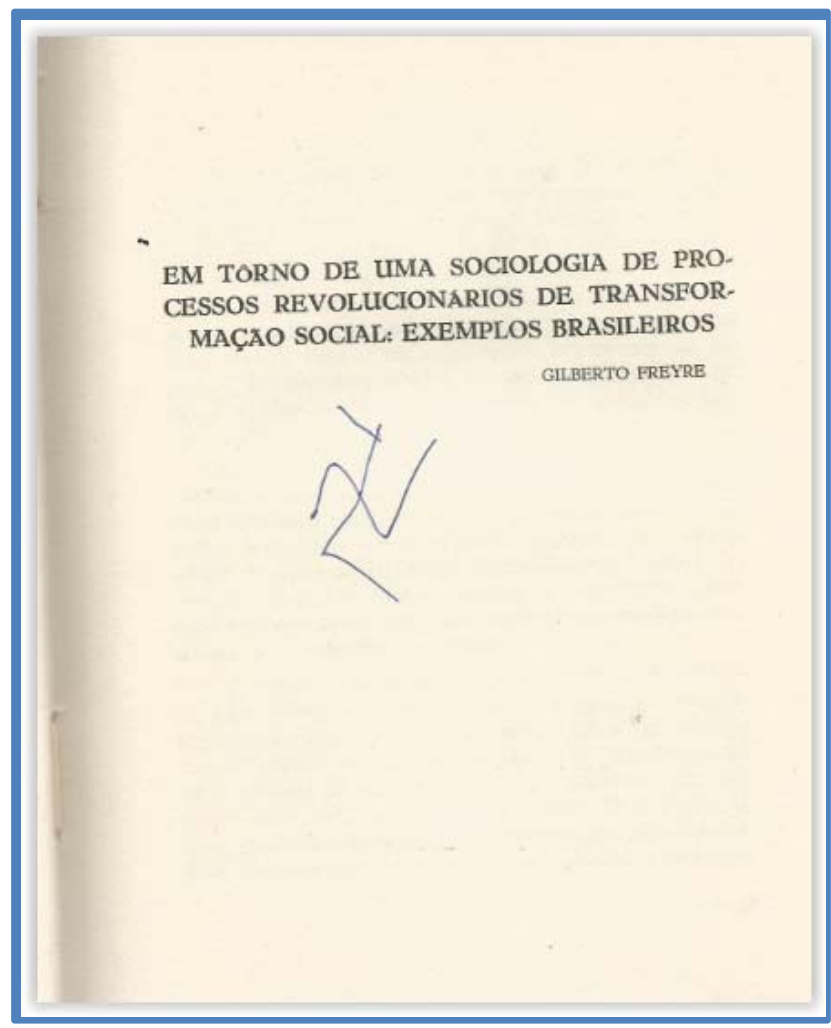

Imagem 21 


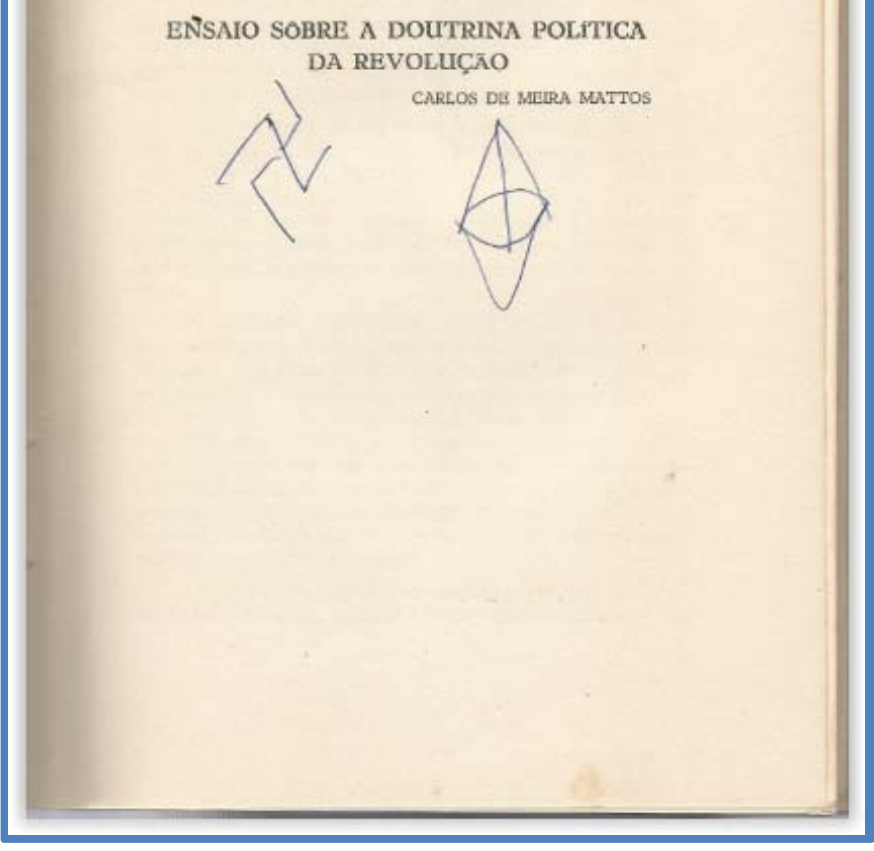

Imagens 22

No caso do general Meira Mattos, recorde-se que ele presidiu comissão instituída em 1967 pelo ditador Costa e Silva (FÁVERO, 1991), voltada especificamente para o que o governo considerava como "problemas estudantis". De acordo com o relatório final do trabalho dessa comissão, os estudantes brasileiros estavam à mercê de infiltrações "subversivas", devido à "inexistência de uma liderança estudantil democrática autêntica". Com isso, os estudantes abandonavam a atividade que seria a finalidade e o sentido de sua existência, o estudar, passando a se ocupar de assuntos políticos. A situação era agravada, ainda de acordo com o relatório, devido à má administração das universidades, de sua expansão descontrolada e de formas mal desenhadas de financiamento. Daí as propostas no sentido de "racionalizar" a administração, talvez implementar cobrança de mensalidades, controlar as infiltrações de "subversivos" e, ao mesmo tempo, criar mecanismos governamentais de formação de uma juventude “democrática" - o que, no vocabulário invertido da ditadura, queria dizer exatamente o contrário de democracia. 


\subsection{Os subversivos, livro de Bernard Hutton}

O destaque final fica por conta do livro Os subversivos de Hutton (1972). O livro foi indicado como leitura básica para a formação de agentes dos serviços de espionagem na universidade, em circular do Ministério da Educação e Cultura. ${ }^{5}$ A identidade secreta de seu autor é um mistério. Trata-se de um pseudônimo. O conteúdo do livro poderia ser classificado como o de um "folhetim historiográfico", uma vez que ele mistura cenas de melodrama, em cenários que envolvem mistério, sedução e fascínio no submundo dos espiões, com uma narrativa historiográfica que atribui todos os "problemas" do mundo ocidental (da dissolução da família, aos movimentos estudantis, ao consumo de drogas e daí à existência dos Panteras Negras) à ação secreta do Comunismo Internacional.

O exemplar dos rabiscos aqui reproduzidos, consta como sendo doação de ninguém menos do que José Carlos de Almeida Azevedo. Alguém rabiscou no livro o título de Rei-Thor. Uma repercussão de um evento curioso: uma peça teatral. Graças à minúcia dos serviços de espionagem da universidade, sabemos que ela foi encenada no dia 07 de junho de 1977, às 10h30 da manhã, para um público de cerca de 300 alunos:

As 1030h:- Cerca de 300 alunos estavam concentrados no ICC Norte para assistirem a apresentação da peça satírica denominada "O REI THOR E SEU SÉQUITO", com onze elementos, cada um representando os seguintes personagens: "Imprensa", "Dedodurubú", "SPPatrimônio", "Cultura e Ciência", "Planalto", e "Burocracia". Usavam o rosto coberto. Os elementos de imprensa estavam sendo identificados pelos alunos. ${ }^{6}$

O destaque se deve ao fato de que, nesses livros, encontramos praticamente todo o repertório de marginalias aqui analisado. Intervenções textuais e paratextuais, revisões editoriais e a marca da suástica (por sua vez, rabiscada posteriormente por outra mão - talvez simpática ao livro e considerando injusta a associação com o nazismo?).

\footnotetext{
${ }^{5}$ Arquivo Nacional. Memórias Reveladas. Acervo dos órgãos de informação do regime militar, Fundo ASI/UnB BR DF ANBSB AA1 o LGS 008.

${ }^{6}$ Arquivo Nacional. Memórias Reveladas. Acervo dos órgãos de informação do regime militar, Fundo ASI/UnB BR DF ANBSB AA1 o MPL 0111.
} 


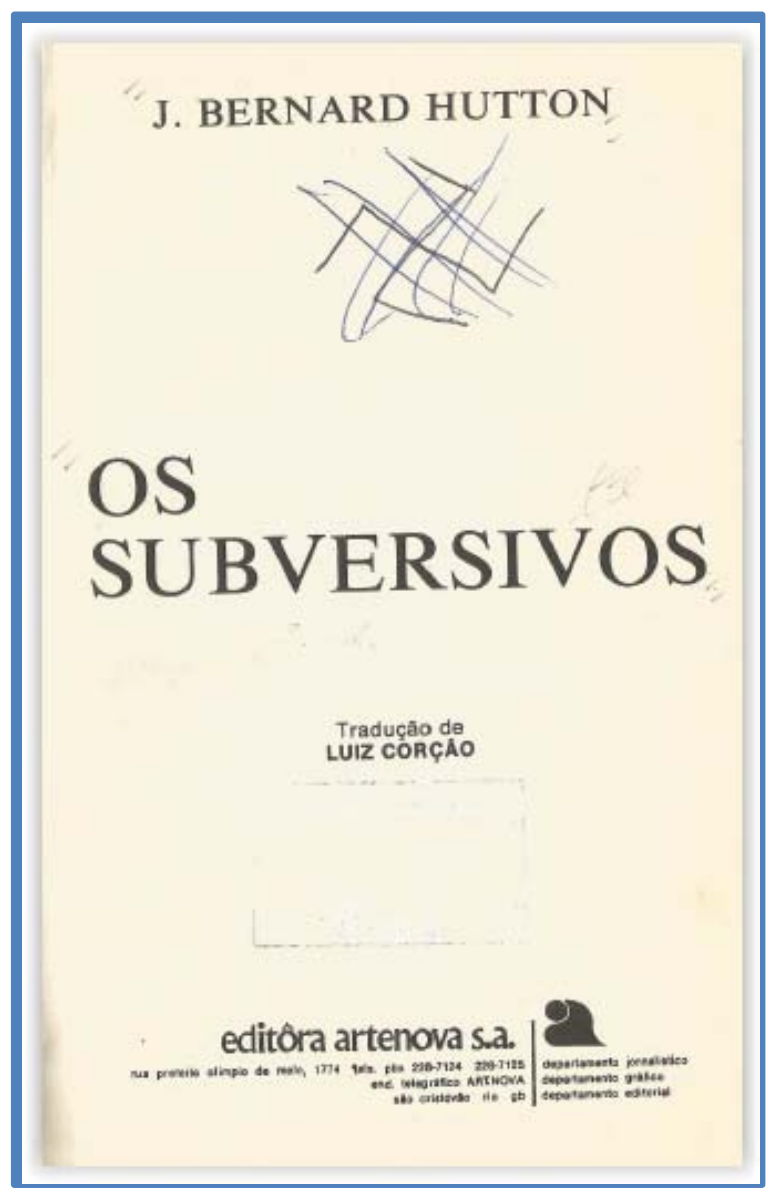

Imagem 23

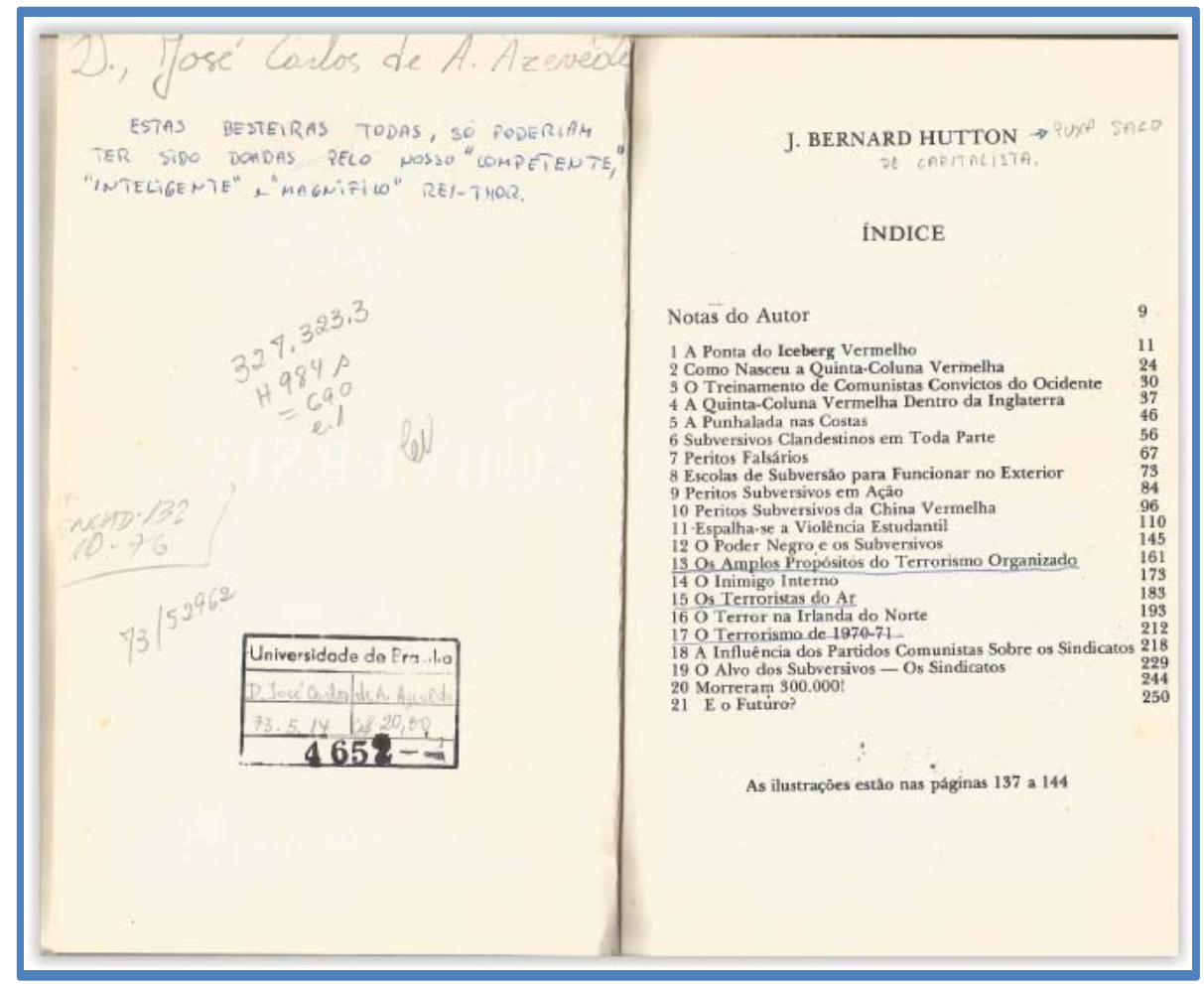

Imagens 24 


\section{Considerações finais}

Num país em que toda literatura comunista está proibida, um livreiro introduz, através de vários pacotes, as memórias de John Rockefeller: Como me tornei milionário. A partir da quarta página, verifica-se que o texto é de Lênin - No caminho da insurreição. (SERGE, [19--]., p. 87)

A coleção de rabiscos, marginalias, estudadas nesse artigo é pensada como um acervo de cacos, restos mesmo. Pequenos sinais de protesto dirigidos a leitores futuros que viriam a tomar aqueles livros em mãos. Talvez, mesmo gestos de simples tomada do direito de ter voz. Em termos políticos ou históricos, esse tipo de marca em livros pode ter muitos sentidos. Num contexto ditatorial, em que todo dissenso é virtualmente criminalizado e em que a universidade é considerada palco de "subversão" latente contra o governo, a questão do direito à voz - e de como sobreviver à imposição do silêncio adquire sentidos específicos, alguns dos quais foram levantados no decorrer desse artigo. As figuras do rei-thor, da suástica, dos textos disciplinares, perfazem uma constelação em torno de um dos temas básicos da política: quem pode e quem não pode falar - e onde, quando e como.

Há, nesses rabiscos, uma atmosfera de raiva contida, de desejo de trocar ideias e proliferação de chistes rebaixadores. Não se pretende com isso exaltar o sentido libertário ou transgressor dessas marginalias. Isso porque elas só fazem sentido em contraste com um ambiente de quase absoluta asfixia cultural e política. Muitos dos temas discutidos pelos anônimos sequer poderiam ser tocados em outros lugares, mesmo no ambiente aparentemente protegido de uma sala de aula. Até por isso, as marginalias sugerem também a presença sufocante do silêncio. Ao mesmo tempo, porém, ao estarem guardadas numa biblioteca pública, essas marginalias acabam adquirindo um paradoxal "lugar de memória". Não por elas mesmas (pelo contrário, a pulsão institucional é a de apagá-las, de "limpar" os livros). Parados na estante ou circulando na universidade, esses mesmos livros preservados por seu valor institucional, acabam disseminando essas vozes, essas pequenas dores revoltadas. 
De Certeau (1998a, p. 46) faz uma distinção cultural e política entre estratégia e tática. A estratégia é o grande cálculo das relações entre forças, que só se torna possível a partir do momento em que um sujeito de querer e poder consegue se isolar de um ambiente, vendo-o de fora, por cima, como se diante de um panorama. A estratégia se dá a partir de uma base para a gestão de suas relações com uma exterioridade. A estratégia, no Brasil da ditadura militar e no caso mais específico do tema desse artigo, pode ser pensada como projetos, discursos em que o dispositivo do Estado, dominado pelo dispositivo militar, circunscreve a universidade e, dentro da universidade, sua biblioteca tendo como alvo específico o corpo estudantil.

A tática, por sua vez, é a arma daquele que não pode contar com um terreno próprio, nem com uma fronteira que o distingue de um outro. O lugar da tática é desenhado pelo outro, o estrategista. A tática depende das oportunidades passageiras do tempo, para então captar em pleno movimento algumas possibilidades de ganho, que ela, contudo, não guarda para si. Em síntese, o fraco tira partido de forças que lhe são estranhas. É no coração da universidade pública vigiada, na sua biblioteca, espaço sensível em que a distribuição das verdades e das disciplinas é monitorada por todo um aparato ditatorial - é nesse lugar, nas páginas do objeto que se tornou fetiche daquela mesma verdade, o livro - que surgem espaços escondidos, pedaços de papel em branco, lacunas, em que vozes plurais, anônimas, vão cumprir o seu papel de, como dizia o poeta, “desafinar o coro dos contentes”, compondo uma espécie de memória do que poderia ter sido esquecido. 


\section{Referências}

ANDRADE, Carlos Drummond de. Nova reunião:19 livros de poesia. Rio de Janeiro: José Olympio, 1983.

ÁVILA, Padre Fernando Bastos de (Org.). Pequena enciclopédia de moral e civismo. Rio de Janeiro: FENAME, 1978.

BLANCHOT, Maurice. Écrits politiques: 1953-1993. Paris: Gallimard, 2008.

BRASIL. PRESIDÊNCIA . O processo revolucionário brasileiro. Brasília: Assessoria Especial de Relações Públicas, 1969.

COMISSÃO ANISIO TEIXEIRA DE MEMÓRIA E VERDADE. Relatório. Brasília: FAC-UnB, 2016.

DE CERTEAU, Michel. A invenção do cotidiano. Petrópolis: Vozes, 1998a.

DE CERTEAU, Michel. The capture of speech and other political writings. Minneapolis: University of Minnesota Press, 1998.

DELEUZE, Gilles; GUATTARI, Félix. 587 A.C. - 70 D.C.: sobre alguns regimes de signos. Mil Platôs. Capitalismo e esquizofrenia. Vol.2. Trad. Ana Lúcia de Oliveira e Lúcia Cláudia Leão São Paulo: Editora 34, 2008.

FÁVERO, Maria de Lourdes de Albuquerque. Da universidade "modernizada" à universidade disciplinada: Atcon e Meira Mattos. São Paulo: Cortez, 1991.

FICO, Carlos. Como eles agiam: Os subterrâneos da ditadura militar: espionagem e polícia política. Rio de Janeiro, São Paulo: Record, 2001.

FINAZZI-AGRO, Ettore. Entretempos: mapeando a história da cultura brasileira. São Paulo: UNESP, 2013.

FLUSSER, Vilém. A escrita: há futuro para a escrita. São Paulo: Annablume, 2010.

GENETTE, Gérard. Paratextos editoriais. São Paulo: Ateliê Editorial, 2009.

GROYS, Bori. Under suspicion: a phenomenology of media. New York: Columbia University Press, 2012.

HUTTON, J. Bernard. Os subversivos. Rio de Janeiro: Artenova, 1972. 
JOFFILY, Mariana. No centro da engrenagem: os interrogatórios na Operação Bandeirante de São Paulo (1969-1975). São Paulo: EdUSP, 2013.

LEWINO, Walter. L'imagination au pouvoir. Paris: Le Terrain Vague, 1968.

MACHADO NETO, Antonio. "A ex-Universidade de Brasília. Significação e crise”, in: Revista Civilização Brasileira, Rio de Janeiro, ano 3, no 14, julho de 1967, p. 139-158

MCLUHAN, Marshall. Os meios de comunicação como extensões do homem. Trad. de Décio Pignatari. São Paulo: Cultrix, 1969.

MENEZES, Djacir Menezes. Ideias contra ideologias. A revolução silenciosa nas universidades e a ramificação de suas teses. Rio de Janeiro: $G B, 1971$.

PARUCKER, Paulo. A UnB na teia de segurança e informações. In: Marcelo Mari e Priscila Rossinetti Rufinoni. Ditadura, modernização conservadora e universidade: debates sobre um projeto de país. Goiânia: Editora UFG, 2015, p. p. 221-251.

PEREIRA, Mateus Henrique de Faria. "Nova direita? Guerras de memória em tempos de Comissão da Verdade (2012-2014)", in: Varia Historia, Belo Horizonte, vol. 31, n. 57, p. 863902, set/dez 2015.

RANCIÈRE, Jacques. Políticas da escrita. Rio de Janeiro: Editora 34, 1995

TCHOU, Claude (ed.). les murs ont la parole. Mai 68. Paris: Tchou, 1968. 